\title{
Taxonomy and evolution of the protomonaxonid sponge family Piraniidae
}

\author{
Joseph P. Botting, Sarah E. Stewart, Lucy A. Muir, and Yuandong Zhang
}

\begin{abstract}
The protomonaxonid sponge Pirania is an iconic member of the Burgess Shale community, but recent discoveries show that piraniids are morphologically diverse and also occur in Ordovician strata. Here we establish three new piraniid genera on the basis of Ordovician material from China, Wales, Scotland and Morocco: Auraeopirania gen. nov., Cannapirania gen. nov. and Pellipirania gen. nov. We also establish eight new species: Pirania? peregrinata sp. nov. (Lower Ordovician Ningkuo Formation, China); P.? ericia sp. nov. (Lower Ordovician Afon Gam Biota, Wales); Auraeopirania pinwyddeni gen. et sp. nov. (Middle Ordovician Llanfallteg Biota, Wales); A. pykitia gen. et sp. nov. (Upper Ordovician, Scotland); A. sciurucauda gen. et sp. nov. (Early Ordovician, China); Cannapirania canna gen. et sp. nov. (Middle Ordovician Llanfawr Mudstones, Wales); C. vermiformis gen. et sp. nov. (Upper Ordovician Anji Biota, China); and Pellipirania gloria gen. et sp. nov. (Lower Ordovician Fezouata Biota, Morocco). Piraniids have now been widely reported (South China, Avalonia, Laurentia and Gondwana) from Ordovician strata, but in Cambrian strata have been documented only from the Burgess Shale. The Burgess Shale species Pirania muricata appears to be among the most derived members of the Piraniidae, implying a substantial hidden Cambrian diversity of piraniids. Over the family's history there is a tendency for species to become smaller and inhabit deeper-water environments.
\end{abstract}

Joseph P. Botting. Nanjing Institute of Geology and Palaeontology, 39 East Beijing Road, Nanjing 210008, China. corresponding authors acutipuerilis@yahoo.co.uk

Department of Natural Sciences, Amgueddfa Cymru - National Museum Wales, Cathays Park, Cardiff CF10 3NP, UK.

Sarah E. Stewart. National Museums Scotland, Chambers Street, Edinburgh EH1 1JF, UK.

sarah.stewart@nms.ac.uk

Lucy A. Muir. Department of Natural Sciences, Amgueddfa Cymru - National Museum Wales, Cathays Park, Cardiff CF10 3NP, UK. lucy@asoldasthehills.org

Yuandong Zhang. State Key Laboratory of Palaeobiology and Stratigraphy, Nanjing Institute of Geology and Palaeontology

Center for Excellence in Life and Paleoenvironment, Chinese Academy of Sciences, 39 East Beijing Road,

http://zoobank.org/283E70EA-5A6A-498A-9F73-E8D2A7D81617

Botting, Joseph P., Stewart, Sarah E., Muir, Lucy A., and Zhang, Yuandong. 2019. Taxonomy and evolution of the protomonaxonid sponge family Piraniidae. Palaeontologia Electronica 22.3.76. 1-27. https://doi.org/10.26879/998

palaeo-electronica.org/content/2019/2825-piraniidae-revision

Copyright: December 2019 Paleontological Society.

This is an open access article distributed under the terms of Attribution-NonCommercial-ShareAlike 4.0 International (CC BY-NC-SA

4.0 ), which permits users to copy and redistribute the material in any medium or format, provided it is not used for commercial

purposes and the original author and source are credited, with indications if any changes are made.

creativecommons.org/licenses/by-nc-sa/4.0/ 
Nanjing 210008, China. corresponding author ydzhang@nigpas.ac.cn

Keywords: new genus; new species; Porifera; Protomonaxonida; evolution

Submission: 11 May 2019. Acceptance: 28 October 2019.

\section{INTRODUCTION}

Pirania Walcott, 1920, is a widespread and distinctive genus of Cambrian and Ordovician sponges. The type species is one of the most iconic Burgess Shale taxa and has attracted attention also due to coevolution with epibiotic brachiopods (Topper et al. 2015; Vinn 2017). At present the family Piraniidae is effectively monogeneric, consisting only of Pirania and supposedly the poorly-known genus Moleculospina (discussed herein); the diagnosis of the family (Finks and Rigby, 2004) is based primarily on the body shape combined with the projecting, round-based spicules. Pirania has also been implicated in the debate over the phylogenetic affinity of chancelloriids, because it possessed all of the key characters of that otherwise enigmatic group, and has been suggested to represent their ancestral condition (Botting and Muir, 2018). Within sponges, there is a continuum between Pirania and other protomonaxonids, showing the origination of their most peculiar characters such as hollow, open-based sclerites rather than solid spicules (Botting et al., 2013). It is therefore a key genus among early sponge faunas, but the differences between described species are substantial and complicate understanding; a synoptic understanding of the taxonomy of the genus is overdue.

Pirania has been reported from North America (Walcott, 1920; Rigby, 1986; Rigby and Collins, 2004), Bohemia (Príbyl, 1947), Avalonia (Botting, 2004) and Morocco (Botting, 2007) but has not previously been described from elsewhere. The distinctiveness of the genus, with a tubular body form and prominent prostalia, disguises differences between the described species. Based on the discovery of new taxa from China, Morocco, Scotland and Wales, and previously unrecognised material from the Burgess Shale, those differences are now becoming consistent and recognisable. As a result of these discoveries, subdivision of the genus is now unavoidable. In this paper, we establish a new taxonomic framework for the Piraniidae, describe all the currently available new material, and add descriptions of taxa that expand the morphological scope of the family.

\section{GEOLOGICAL BACKGROUND}

The new material described here is from several previously described sites, and we refer readers to earlier papers for full geological contexts. We provide brief details of the localities and ages of the deposits below, in order of age, with occurrences and palaeogeographic locations summarised in Figure 1.

The oldest Ordovician deposit is the Afon Gam Biota, North Wales, UK (Conophrys salopiensis Biozone, early late Tremadocian), which is dominated by sponges (Botting and Muir, 2014; Botting et al., 2015). A diverse range of protomonaxonids and hexactin-bearing taxa were preserved in turbiditic mud-flows representing an uncertain water depth. The presence of diverse other taxa, including well-preserved algae, suggests relatively shallow conditions equivalent to the deeper part of the shelf; this is supported by the similarity of the trilobites to more inshore communities such as the Sheinton Shales (Botting et al., 2015).

The Fezouata Biota (late Tremadocian to early Floian, with most exceptional preservation in the Araneograptus murrayi Biozone) is a Lower Ordovician sequence of storm-influenced shelf deposits with abundant exceptional preservation (Van Roy et al., 2010; Martin et al., 2016), including sponges (Botting, 2016). Like many other fossil groups in the deposit, sponges tend to be found as mass occurrences (usually monospecific), probably representing opportunistic colonisation of the sea floor during suitable environmental conditions (Botting, 2016; Saleh et al., 2018), although piraniids tend to occur as isolated individuals at many sites (Botting, 2016).

The Llanfallteg Biota (Hearing et al., 2016) of South Wales, UK, is Middle Ordovician in age (Darriwilian, Didymograptus artus Biozone), with a sparse but exceptionally preserved benthic fauna buried within muddy slump material deposited in deep water within a volcanically active area. The associated fauna includes Burgess Shale-type arthropods (marrellomorph and xenopod), trilobites, ceratiocarids, palaeoscolecid and annelid worms, rare echinoderms, other sponges and lingulate brachiopods. The single piraniid sponge 

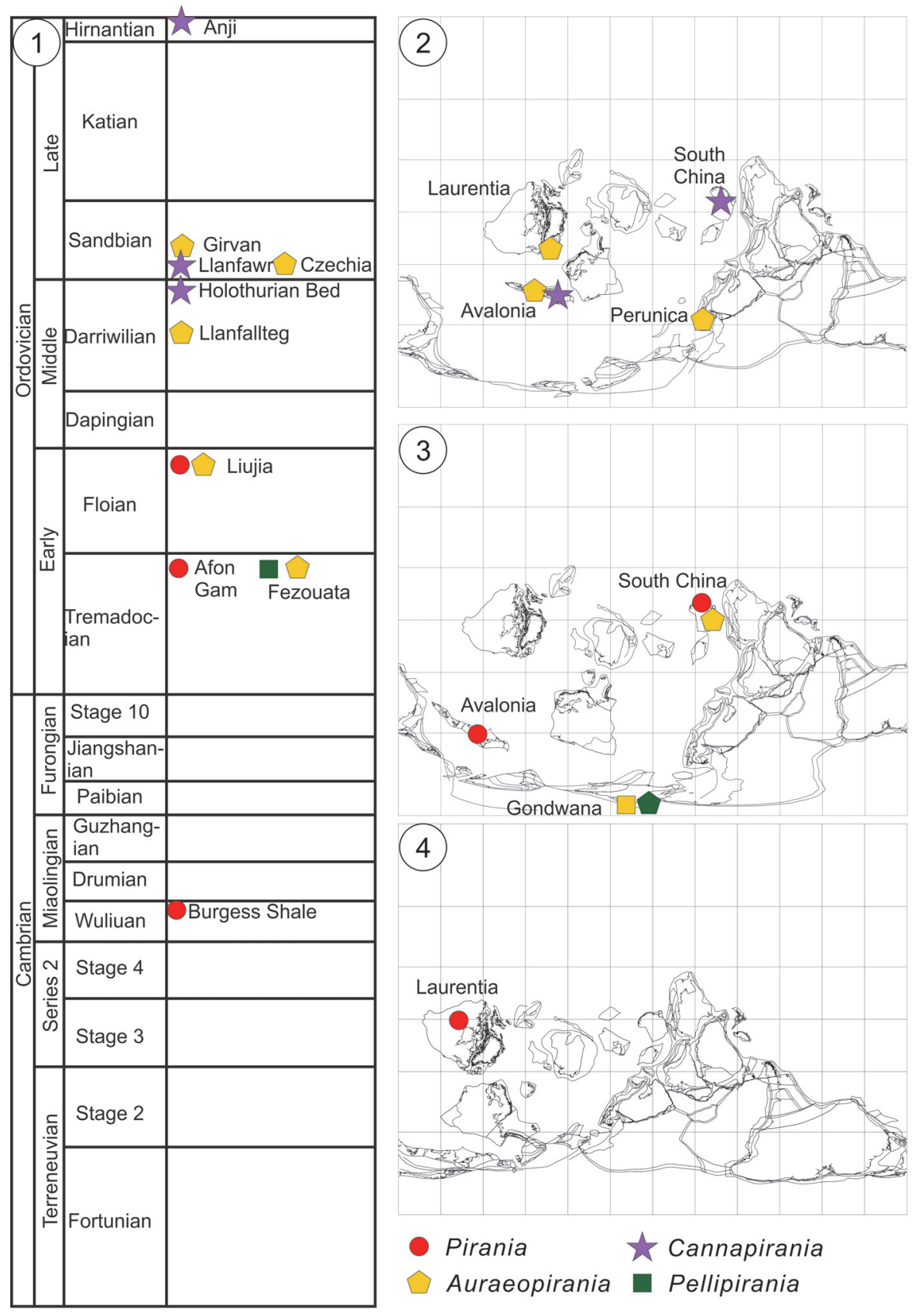

FIGURE 1. Stratigraphic and palaeogeographic distribution of piraniids, including Pirania and three new genera erected in this paper. 1, stratigraphic distribution of piraniids; 2, distribution of piraniids during the Middle and Late Ordovician (Katian, $455 \mathrm{Ma}$ ); 3, distribution of piraniids during the Early Ordovician (Floian, $478 \mathrm{Ma}$ ); 4, distribution of piraniids during the middle Cambrian (515 Ma). Base maps produced using BugPlates (Torsvik 2009).

was previously illustrated by Hearing et al. (2016, fig. $2 h$ ).

The species from Bach-y-Graig is one of a number of currently undescribed sponges from the Holothurian Bed of the Builth Inlier, central Wales (Botting and Muir, 2012; Muir and Botting, 2015). This is from the lower Hustedograptus teretiuscu- lus Biozone, upper Darriwilian (Llanfawr Mudstones Formation), and is found together with a diverse fauna including other sponges, trilobites, echinoderms, brachiopods, palaeoscolecid worms and ostracodes (Botting and Muir, 2012). The environment is inferred to have been relatively deep water (perhaps near to $200 \mathrm{~m}$, based on the 
appearance of cyclopygid and agnostid trilobites), with rapid episodic sediment input on the side of an eroding volcanic cone (Botting and Muir, 2012), and specifically for this bed, elevated sedimentation rate following volcanic ash deposition and remobilisation.

In Scotland, the Ordovician succession of Girvan contains a diversity of facies from shallowwater carbonates to deep-water siliciclastics (Ingham, 2000) on the edge of Laurentia, and the piraniid sponges described here are known from a single, highly unusual fossil assemblage in the Laggan Member of the Balclatchie Formation. The Laggan Member is known for Bulman's (1944-47) work on three-dimensionally preserved graptolites. Williams (1963) later described a deep-water brachiopod fauna and Tripp (1980) described a deepwater trilobite fauna, similar to that of the Pumphouse Member (formerly Balclatchie Mudstones) of Balclatchie, Girvan and equivalent to the Edinburg Formation, Virginia. Bergström(1990) identified an in situ conodont fauna from the Baltoniodus gerdae subzone, at Bulman's locality, and chitinozoans suggestive of a lower Caradoc biozone were described by Vandenbroucke et al. (2003, for 2002). Harper and Owen (1986) described Diacanthaspis trippi (a blind odontopleurid trilobite) and the orthid brachiopod Onniella williamsi from a site close to the localities described by Williams (1963) and Tripp (1980). Both species represent unique occurrences and are not found in the Williams and Tripp faunas. Arthropod fragments and rare specimens of the deep-water brachiopod Foliomena and the planktonic cyclopygid trilobite Microparia are also present (Stewart and Owen, 2008), indicating migration from Gondwana into the deep waters of the Laurentian shelf. Most of the sponge specimens are from this type locality, a small tributary of the Laggan Burn (Harper and Owen 1986), including on the type slab of $D$. trippi. A locality nearby, Dalfask Quarry, contains an unusual fauna of $D$. trippi, O. williamsi, the polyplacophoran Solenocaris solenoides (Stewart and Owen, 2008), the mitrate Anatifopsis sp. and a bizarre spiny ctenocystoid (Rahman et al., 2015), together with an additional piraniid specimen. The sponges are associated with diplograptids, brachiopods and a probable arthropod fragment.

In China, two piraniid species are known from the Liujia locality, of Floian (Early Ordovician) age (Corymbograptus deflexus Biozone, Ningkuo Formation), which has previously yielded the problematic sponge Heteractenigma yui (Botting and Zhang, 2013). Additional undescribed sponges are also present in the fauna, but are generally less well preserved; other than sponges, the assemblage is restricted to graptolites and caryocarid crustaceans. The formation at the Liujia section is composed of laminated or massive green mudstones, representing a generally quiescent slopebasin area (Zhang et al., 2010).

The Anji Biota (Botting et al., 2017) of Zhejiang Province, China, has yielded an extraordinarily rich assemblage of sponges from the uppermost Ordovician (Hirnantian, Metabolograptus persculptus Biozone). This deep-water, basinal fauna includes very few fossils other than sponges and graptolites (rare nautiloids and a single specimen of an articulated eurypterid); other arthropods are also present, but very scarce. The new piraniid from the Anji Biota is from the major locality Zhuwukou, level ZWK3 (see supporting online material of Botting et al., 2017), at which point the water depth was beginning to shallow relative to the massive black mudstones of the central part of the sequence. The absolute depth remains uncertain, but these deposits occur in a transgressive interval, between thick turbidite sequences and contain numerous sponges that are typical of bathyal to absyssal habitats, such as rossellids (Botting et al., 2018); a plausible estimate for water depth is therefore several hundred metres.

\section{MATERIALS AND METHODS}

Type and figured material is deposited in several institutes: the Nanjing Institute of Geology and Palaeontology, Nanjing, China (NIGP); Amgueddfa Cymru - National Museum of Wales, Cardiff, UK (NMW); and the Hunterian Museum, Glasgow, UK (GLAHM).

Images were obtained primarily with a Nikon D80 DSLR camera with a $105 \mathrm{~mm}$ macro lens and a Zeiss Discovery V20 stereomicroscope with an Axiocam 506; some detail views were obtained using a high-magnification USB microscope.

\section{SYSTEMATIC PALAEONTOLOGY}

\section{Phylum PORIFERA Grant, 1836 "PROTOMONAXONIDA"}

Remarks. The Protomonaxonida was erected by Finks and Rigby (2004) to accommodate a heterogeneous assemblage of early Palaeozoic, monaxon-bearing sponges. This was shown by Botting et al. (2013) to constitute at least two distinct groups, one consisting of basal demosponges and one of a much more basal lineage, perhaps in the stem group of Porifera (Botting and Muir, 
2018). The term 'protomonaxonid' has until now been retained informally to refer to this earlier group, which may or may not include the Family Leptomitidae (Botting and Zhang, 2013; Botting and Muir, 2018). Additional information regarding the earliest members of these groups (particularly in relation to the Leptomitidae) is desirable before conducting a formal diagnosis of the protomonaxonids.

Family PIRANIIDAE de Laubenfels, 1955

Diagnosis. (emended after Finks and Rigby, 2004). Subcylindrical to obconical, sometimes branching, protomonaxonid sponges with wide, deep spongocoel; prominent prostalia consisting of enlarged monaxons, often with thick organic outer layer, the points directed outwardly and usually upwardly; outer surface of body may be covered (in part or whole) by parallel projecting array of small oxeas.

Remarks. The family Piraniidae was previously monogeneric. Aside from Pirania, only Moleculospina mammillata (Walcott, 1920) has at any point been referred to the family (Rigby, 1986; Finks and Rigby, 2004), but Moleculospina shows an entirely different organisation, and shares with Pirania only a spicule arrangement in which tufts of fine spicules surround isolated larger ones. In all other respects it appears to be a very different sponge and should be regarded as of uncertain higher taxonomy; it is currently in need of detailed re-examination, ideally based on additional material.

As discussed by Botting (2007), the genus Pirania as previously applied includes substantial differences in morphology, exemplified by the type species P. muricata Walcott, 1920 (Burgess Shale, middle Cambrian of Canada), the cylindrical, densely spiculate $P$. auraeum Botting, 2007 (Fezouata Biota, Lower Ordovician of Morocco), and the small, tubular P. Ilanfawrensis Botting, 2004 (Llanfawr Mudstones, Upper Ordovician of Wales). The specimen illustrated by Botting et al. (2015; Afon Gam Biota, Lower Ordovician of Wales) most closely resembles $P$. muricata, whereas a new species from the Middle Ordovician of Bach-y-Graig, Wales, noted by Muir and Botting (2015), is similar to P. Ilanfawrensis from the same formation (described below). The consistencies now being revealed by new discoveries of this generally rare group imply that separation of the genus into several genera is warranted. Additional, poorly known taxa such as the large 'piraniid $A$ ' of Botting (2016) from the Fezouata Biota of Morocco, also require the erection of additional genera, and somewhat expand the scope of the family.
No other sponge genera have yet been assigned to the Piraniidae, although there are some potential parallels in other taxa. Trichospongiella Rigby, 1971, was based on a single specimen of a peculiar supposed sponge from the Upper Ordovician Cat Head Biota of Canada. Although it has some features resembling Pirania, including an elongate body with projecting spines, there are several anomalies. The spines appear to originate largely from a longitudinal groove, and the outline (including the 'base') of the sponge is asymmetric. Additional material is needed, and it is possible that Trichospongiella is instead a spinose appendage of a large arthropod.

\section{Genus PIRANIA Walcott, 1920}

Type species. Pirania muricata Walcott, 1920, from the middle Cambrian Burgess Shale, Canada, by original monotypy.

Diagnosis (emended). Steeply obconical to conicocylindrical, solitary or branching sponges with narrowed osculum and sparse array of robust prostalia that are organic-walled and open-based; no distinct marginalia; wall shows reticulate structure of uncertain nature (perhaps tufts of minute spicules or small platelets).

Remarks. The name Pirania is tied to the type species, P. muricata Walcott, 1920, and the generic diagnosis is based on this species. Not all characters are likely to be visible in all material; the dermal texture, in particular, probably requires extreme exceptional preservation as in the Burgess Shale. It is the type species, in particular, that shows a strong similarity to the Chancelloriidae (Botting and Muir, 2018). The new species included here share fundamental features of the skeleton and body form with P. muricata, but generally do not show the finest details needed for certain attribution to the genus. Furthermore, the conical body form appears to be a primitive feature of the genus, and therefore it is likely that the lineage leading to Pirania and the chancelloriids was morphologically similar to the species described here. Taxonomically, a sister-group relationship to chancelloriids (Botting and Muir, 2018) must restrict Pirania to species bearing at least the derived characteristics of the problematic 'dermal' structure, together with reduction of the mineral component of the spicules and emphasis of the organic component. As a result, species assigned here to Pirania are included questionably, and may represent more basal positions.

Other species. Questionably, Pirania? ericia sp. nov. and $P$.? peregrinata sp. nov. 

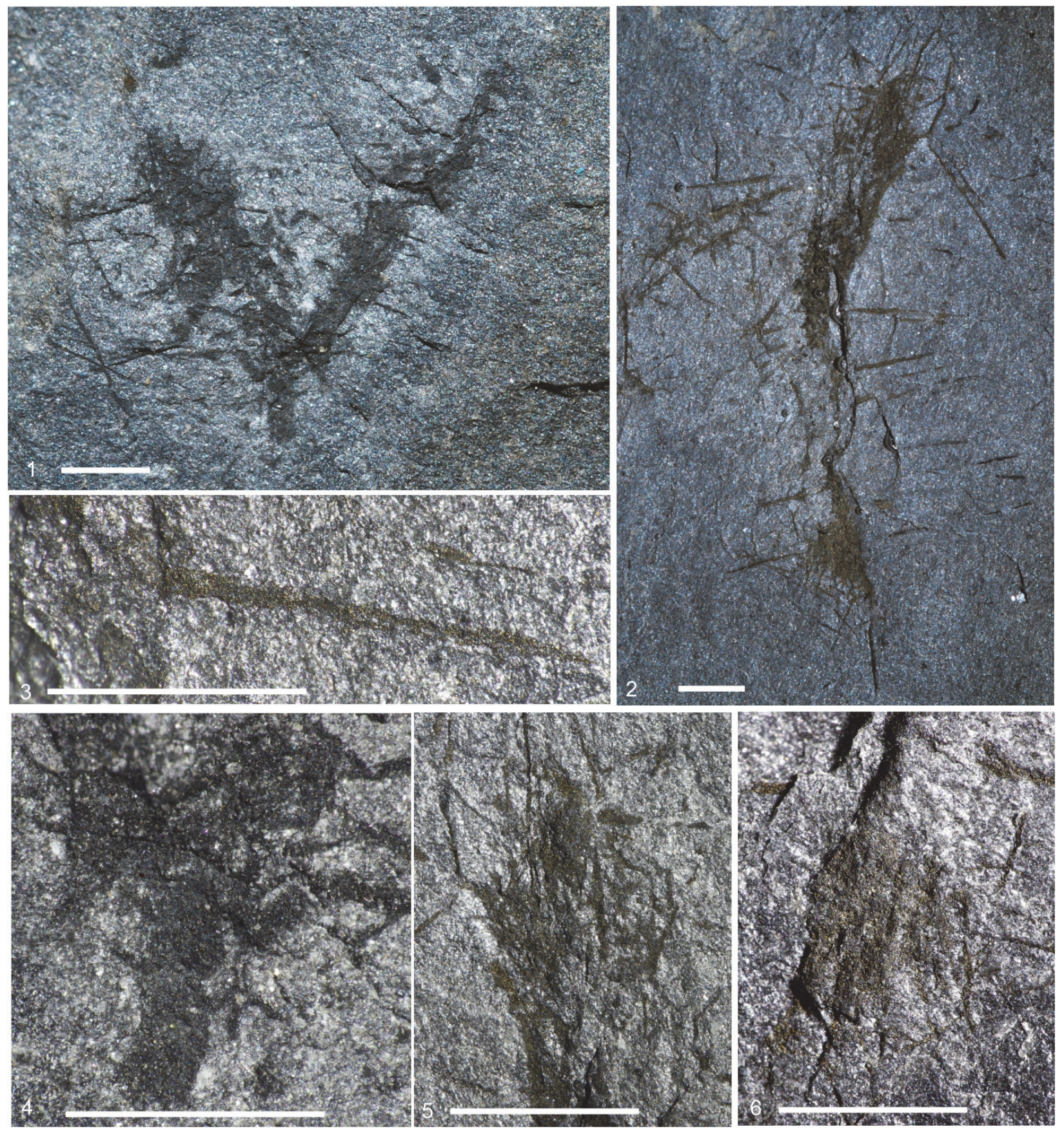

FIGURE 2. Pirania? ericia sp. nov., from the Early Ordovician (Tremadocian) Afon Gam Biota, North Wales. 1, 4: holotype NMW2015.34G.26; 1, overall view of branched specimen, and 4, detail of truncated basal stalk (counterpart). 2-3, 5-6, paratype NMW2015.34G.31; 2, overall view of unbranched sponge; 3, detail of well-preserved lateral prostalial spicule with wide base; 5 , detail of flared apex showing finer spicules between prostalia; 6 , detail of basal tuft of radiating fine and coarse spicules. Scale bars equal $1 \mathrm{~mm}$.

\section{Pirania? ericia sp. nov.}

Figure 2

zoobank.org/A3A2BDF1-457A-4F61-B3CF-220F20BF1380

2015 Pirania sp. Botting et al., p. 7, fig. 5j.

Name. Latin, after a street urchin or ragamuffin, for its small size and unkempt appearance.
Diagnosis. Small, narrow conical sponge, sometimes branching, with sparse but robust prostalia, the largest at least twice maximum body width; prostalia straight, normally projecting perpendicularly to body wall; basal area with narrow stalk, but attachment not seen. 
Holotype. NMW 2012.36G.26, complete branching specimen, from the Conophrys salopiensis Biozone (Ordovician, Tremadocian) Dol-Cyn-Afon Formation of the stream section at Amnodd Bwll, near Bala, North Wales (UK grid reference SH80753690).

Paratype. NMW 2012.36G.31, larger, solitary and somewhat disarticulating specimen, from the type locality.

Description. Both spicules and body region preserved as replacement by dense array of iron sulphide framboids. Small, narrow piraniid with paratype (single branch) $11 \mathrm{~mm}$ long and maximum $1.5 \mathrm{~mm}$ wide (Figure 2.2), but perhaps attenuated somewhat during decay; holotype (Figure 2.1) has two branches, 5 and $4 \mathrm{~mm}$ long, each up to $1 \mathrm{~mm}$ wide. Description below is based primarily on holotype, except where stated.

Branches widen irregularly from $0.5 \mathrm{~mm}$ at base to maximum $(1.0 \mathrm{~mm})$ near osculum; apex poorly preserved but appears abruptly rounded in holotype, indicating rapid narrowing; paratype suggests abrupt end without significant narrowing, but may be distorted. Body margin, particularly in basal part, with sharply defined margins and no indication of projecting spicules except for primary prostalia. Within lower part of pyritised body area (Figure 2.4) are faint impressions of dense array of short monaxon spicules (estimated up to $0.2 \mathrm{~mm}$ long, and very fine), creating a dominantly longitudinal fabric. This fabric is lost in upper part of the holotype, perhaps taphonomically due to higher numbers of prostalial bases combined with thicker body wall preservation, but is visible in apical region of paratype. Oblique spicules also present within longitudinal fabric, but may be overlain prostalia.

Body margin pierced by numerous, but sparsely distributed prostalia, the wall margin curving out slightly to produce cuspate structures at their base. Typical longitudinal spacing of most prominent prostalia along middle part of body is $0.3-0.5 \mathrm{~mm}$ in holotype, but closer to $1 \mathrm{~mm}$ in paratype; if not related to post-mortem distortion, this suggests that the body expanded during growth without addition of numerous new prostalia. Apical region with much denser array of prostalia, in confused arrangement; in paratype, some appear vertical and others angled across them.

Prostalia of variable length but typically twice maximum width of sponge; in paratype, this is up to $4 \mathrm{~mm}$, and in holotype up to $2 \mathrm{~mm}$. Where clearly preserved (Figure 2.3), spicules appear to taper evenly from wide base (up to $0.2 \mathrm{~mm}$ in paratype;
$0.1 \mathrm{~mm}$ in holotype), which shows no evidence of proximal tapering or rounded base, and is entirely infilled or replaced by framboids. Prostalia project nearly perpendicularly from the body wall for most of length, and are entirely straight.

Basal region broken off in holotype, but possibly preserved in paratype (Figure 2.6) as flared, radiating array of spicules up to $1 \mathrm{~mm}$ wide, including fine and coarse monaxons, the latter up to 2 $\mathrm{mm}$ long and resembling lateral prostalia. Body width narrowest immediately above this holdfast structure, at around $0.3 \mathrm{~mm}$.

Remarks. Pirania? ericia sp. nov. is distinguished from other species of Pirania by, particularly, the sparse array of prostalia projecting perpendicularly to the body wall. Although the preservation is limited to coarse replacements of the soft tissue and spicules, preventing confirmation of features such as the dermal texture, the body form and the exclusively coarse, wide-based prostalia are typical of Pirania as now defined. It should be noted, though, that the longitudinal spicules within the body wall and the possibility of a sharply truncated apex are more similar to some other species in the complex, such as Cannapirania canna gen. et sp. nov. Therefore, this species likely preserves some primitive features and is less derived than $P$. muricata.

\section{Pirania? peregrinata sp. nov. Figure 3}

\section{zoobank.org/283E70EA-5A6A-498A-9F73-E8D2A7D81617}

Name. Latin, meaning wanderer or foreigner, recognising the first published record of this widespread genus in China.

Diagnosis. Pirania with narrow tubular body and highly elongate, straight lateral prostalia up to five times as long as body diameter; no distinct marginalia, but narrowed apical region supports some shorter, fine prostalia.

Holotype. NIGP171183 from the upper Floian (Corymbograptus deflexus Biozone) Ningkuo Formation of the Liujia section, Zhejiang Province, China. Only known specimen.

Description. Single specimen is a partial sponge lacking the basal region but with good preservation of distal area (Figure 3.1). Specimen is $11 \mathrm{~mm}$ tall, with narrow, subcylindrical body $2 \mathrm{~mm}$ wide at preserved base, narrowing gradually to $1 \mathrm{~mm}$ at apex. Osculum approximately $0.5 \mathrm{~mm}$ wide, but diameter of internal cavity uncertain; depressed area in apical third suggests roughly half of flattened diameter, at least in this upper region.

Visible spicules consist entirely of lateral prostalia, up to $12 \mathrm{~mm}$ long. Prostalia are entirely straight, up to $0.1 \mathrm{~mm}$ wide at base and tapering 


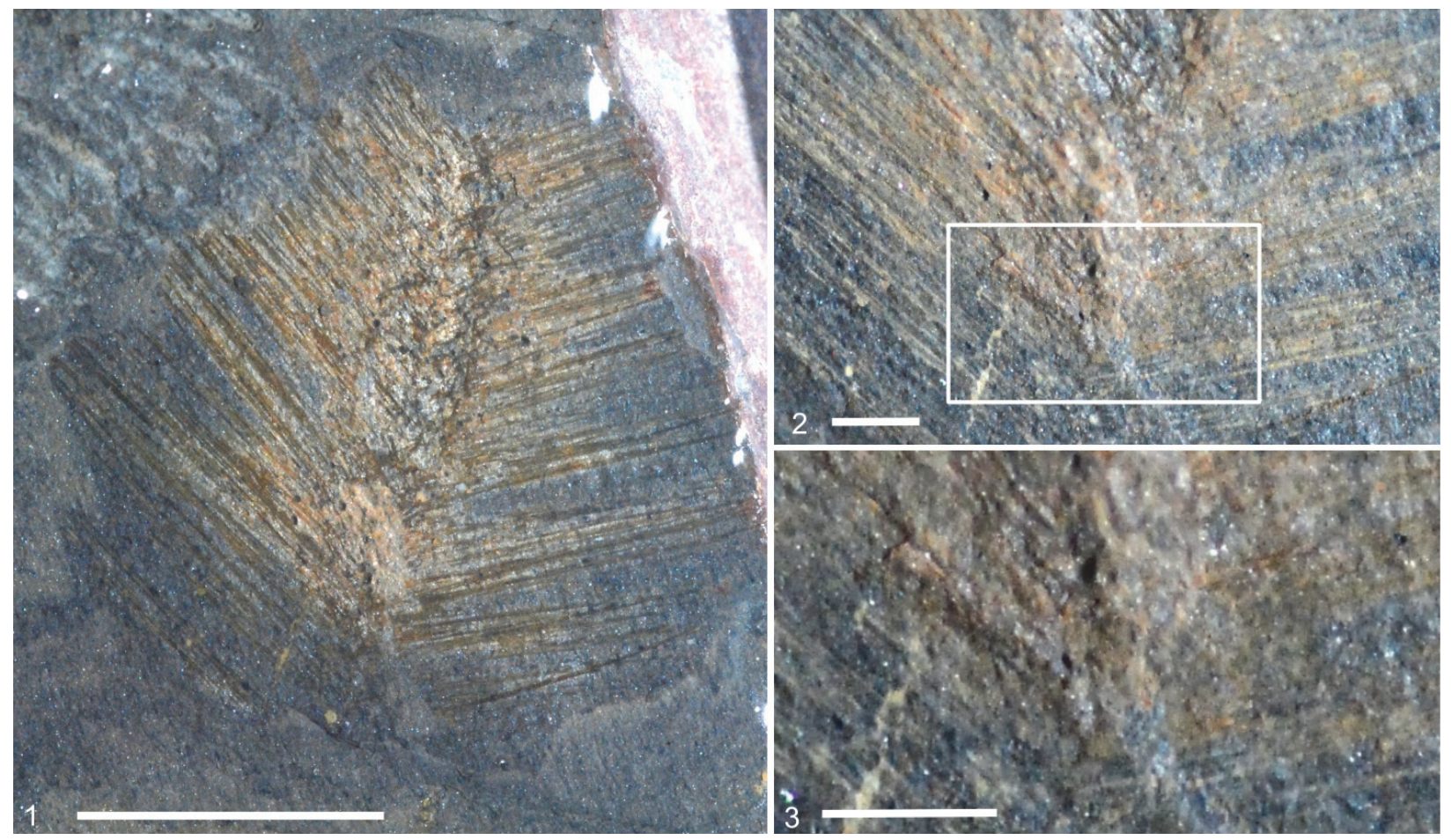

FIGURE 3. Pirania? peregrinata sp. nov. from the Floian Liujia section, Zhejiang, China; NIGP171183. 1, overall view of specimen photographed under water to highlight coarser pyritised spicules; 2, lower part photographed dry with low-angle light, showing array of fine spicules; boxed area magnified in 3, showing lack of basal spicule expansion. Scale bars equal $1,5 \mathrm{~mm} ; 2-3,1 \mathrm{~mm}$.

rapidly in proximal third to less than $0.05 \mathrm{~mm}$, then evenly thereafter to a sharp point. Some show a dark envelope, potentially representing an organic outer lamina. In one area, several spicules are sharply bent through around $10^{\circ}$, close to the body. Bases of coarsest visible primarily where compressed onto the body wall in the upper part, and appear to be expanded, rounded and possible open. Many finer prostalia also present, parallel to coarsest ones, in which the base is not noticeably expanded (Figure 3.3).

Prostalia at consistent angle of approximately $70^{\circ}$ on the right-hand side, and $55^{\circ}$ on the left; the difference is presumed to be related to biostratinomic processes, and a life orientation of around $60^{\circ}$ is plausible. The spicules must have been rigidly attached within the body wall in order to maintain the observed attitude. Prostalia maintain the same orientation along the entirety of the visible margin, up to the apex, where they end abruptly. The apical-most prostalia are somewhat reduced in length, and include a few short, fine spicules but are otherwise similar. No distinct marginalia present, but some sparse, fine spicules present around upper margin; these rotated prostalia may be due to oblique flattening rather than a different angle in life.

No tufts of fine secondary spicules are visible. Body wall texture unclear due to compression and slight deformation of the rock, combined with presence of voids resulting from weathering of pyrite grains, but traces of small (c. $0.5 \mathrm{~mm}$ ) depressions are visible. Base not seen.

Remarks. There have been no previous descriptions of piraniids from China, and this new species shows significant differences to all other described taxa. The closest comparison is with Pirania muricata Walcott, 1920, which has a wider, often conical body and sparser and less regular arrangement of prostalia, which curve upwards towards the osculum (Rigby, 1986; Rigby and Collins, 2004) rather than being straight. The uppermost prostalia are also directed much more vertically. The much smaller Cannapirania llanfawrensis (Botting, 2004) has prostalia barely longer than the body diameter. Auraeopirania auraeum (Botting, 2007) also had a much wider body that shows distinct apical narrowing, and very dense array of fine prostalia; this combination leads to a dense array of marginalia that have a full range of angles up to vertical. 


\section{Genus AURAEOPIRANIA nov.}

zoobank.org/283E70EA-5A6A-498A-9F73-E8D2A7D81617

Type species. Pirania auraeum Botting, 2007, from the Early Ordovician Fezouata Biota of Morocco; designated here.

Name. After the type species, Pirania auraeum (Botting, 2007), where it refers to the curtain-like basal structure.

Diagnosis. Piraniids with tubular bodies and usually narrowed osculum, with dense, continuous array of prostalia rather than robust, separated spines; basal prostalia developed into broad curtain of similar spicules; apical prostalia interspersed with robust marginalia in some species.

Other species. Auraeopirania pinwyddeni sp. nov., A. pykitia sp. nov.; and questionably, Pirania plasi Pribyl, 1947.

Remarks. Recognition of this genus is based primarily on the contrast between the narrow tubular body and the dense array of relatively fine prostalia. Although the type species is well known, the Ordovician P. plasi Pribyl, 1947, from Bohemia, has remained largely unknown, and was overlooked by Rigby (1986), Rigby and Collins (2004) and Botting (2004). Pirania plasi was described on the basis of a single specimen from the upper part of the Dobrotivá Formation (Pribyl, 1947); this formation is now correlated with the upper Darriwilian and lower Sandbian (Bergström et al., 2009; Fatka and Budil, 2014). The single specimen shows a narrow, tubular body (apparently tapering gradually upwards to a narrow, indistinct osculum) that is 23 $\mathrm{mm}$ long, and a dense and irregularly bundled array of prostalia. The prostalia decline markedly in length towards the apex, uniquely for piraniids. The unusual features of this specimen, combined with the limited resolution of the published images, make the assignment to the Piraniidae somewhat uncertain; even the orientation cannot be categorically confirmed. In the absence of further specimens or diagnostic fine details, the species is tentatively accepted as a piraniid and included in Auraeopirania gen. nov.

\section{Auraeopirania pinwyddeni sp. nov. Figure 4}

\section{zoobank.org/283E70EA-5A6A-498A-9F73-E8D2A7D81617}

2016 Pirania sp. Hearing et al., fig. 2H

Name. After the Welsh for pine tree (Pinus), pinwydden, reflecting the similarity in appearance to a pine branch.

Holotype. NMW 00.17G.113, complete or nearcomplete specimen from the Middle Ordovician (Didymograptus artus Biozone, Darriwilian) Llan- fallteg Formation at Rhyd-y-Brown, $2.35 \mathrm{~km}$ ENE of Clarbeston, Pembrokeshire, Wales [SN 06852225]. Only known specimen.

Diagnosis. Narrow-bodied cylindrical Auraeopirania with narrowed basal part and dense array of coarse basal and lateral tylostyle prostalia, 3-4 times body diameter, but lacking intervening fine spicule tufts; no evidence of wall-parallel spicules or upwardly-directed marginalia.

Description. Single specimen (Figure 4.1) preserved as iron-stained spicule mould array with some relief defining body wall. Body $7 \mathrm{~mm}$ long and up to $1.3 \mathrm{~mm}$ wide, near-cylindrical but slightly wider in centre than at base and apex; osculum not noticeably narrowed (Figure 4.2), $1 \mathrm{~mm}$ wide. Base of body tapers sharply over $1.5 \mathrm{~mm}$. Body wall thin (not measurable) and showing relief indicating brittle failure, especially in upper part; therefore originally somewhat rigid and probably spiculate, although skeleton is not generally visible.

Skeleton of radially projecting tylostyles, normally 4-5 mm over most of body, but longer (up to $7 \mathrm{~mm}$ ) in radial basal array. Basal diameter 0.05$0.10 \mathrm{~mm}$, but width constant over much of length rather than evenly tapering; distal tips taper abruptly within the last millimetre. Bases of spicules (Figure 4.3) range from smoothly rounded (styles) to slightly expanded as tylostyles (largest with swollen base up to $0.15 \mathrm{~mm}$ wide). All spicules are straight or very slightly curved, usually evenly in one direction. Orientation of prostalia irregular and differs on the two sides, presumably due to biostratinomic effects, and original orientation of spicules cannot be determined with certainty; however, the specimen shows a distinct change from pointing downwards in the lower part, to more perpendicular in the middle, and perhaps slightly upwards apically. Faint impression of relatively fine sub-longitudinal spicules visible in body wall impression near apex, but the nature of these spicules is unclear; at least $0.4 \mathrm{~mm}$ long, and much finer than prostalia, but terminations not seen.

In basal region (Figure 4.4), a distinct fan of large prostalia, up to $7 \mathrm{~mm}$ long, diverges through an angle of $60^{\circ}$ around the vertical axis. This fan is noticeably denser than the lateral prostalia array, with a distinct edge, even though the lowermost lateral prostalia are rotated downwards to become near parallel to the uppermost basalia. Basalia appear to diverge from a narrow basal extension of the body, extending $2 \mathrm{~mm}$ below the cylindrical part of the body and presumably acting as a root or anchoring structure. 

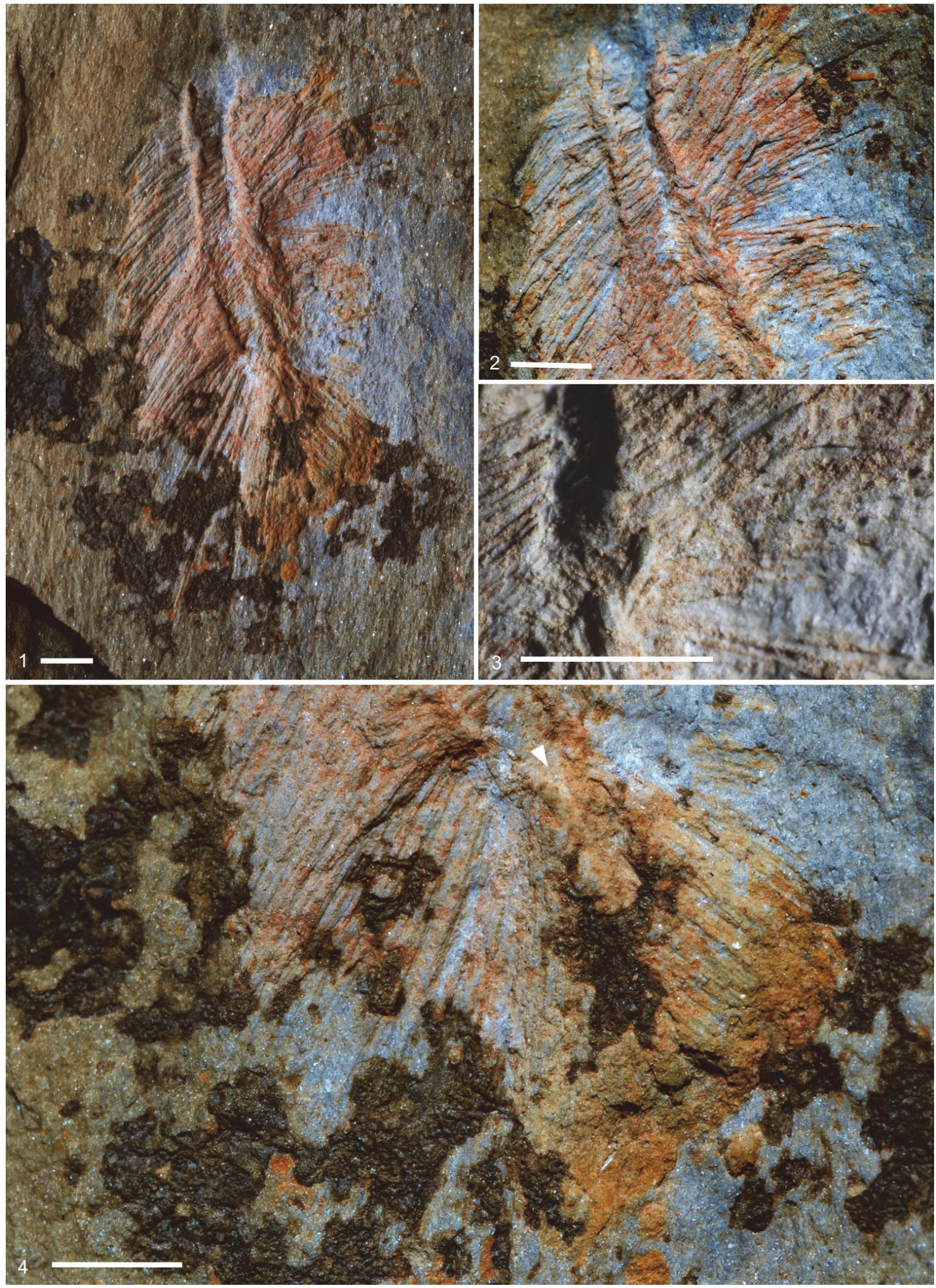

FIGURE 4. Auraeopirania pinwyddeni gen. et sp. nov., from the Middle Ordovician (Didymograptus artus Biozone) Llanfallteg Biota, Rhyd-y-Brown, South Wales; holotype NMW00.17G.113. 1, overall view of specimen; 2, magnification of upper part showing body wall and skeletal organisation; 3 , detail of central part of sponge showing coarse prostalia without obvious fine monaxons; 4 , lower region of sponge, with radiating basal spicule array diverging from narrowed basal part of body (arrowed). Scale bars equal $1 \mathrm{~mm}$. 
Remarks. Although uncertainties remain over some aspects because only a single specimen is available, there is a close similarity in overall form to $A$. auraeum (Botting, 2007). There are also significant differences, however, including the relative robustness of the prostalia, the radial fan of straight basalia rather than the more complex curtain in the type species, and most notably, the apparent lack of an oscular narrowing, which results in the prostalia not closing together over the apex of the sponge. Although some of these features may be disguised by damage to the single specimen of $A$. pinwyddeni, others are unambiguous. The unusual basal structure is very similar to that of the much finer-spiculed $A$. sciurucauda gen. et sp. nov. from Liujia, China.

\section{Auraeopirania sciurucauda sp. nov. Figure 5}

zoobank.org/8CDFBAB4-7032-4D9D-8B68-FFDD087A8896

Name. From Latin sciurus and cauda, referring to a squirrel's tail, for the overall appearance of the sponge.

Holotype. NIGP171184, a semi-complete specimen lacking the apex, from the Floian (Corymbograptus deflexus Biozone) Ningkuo Formation of Liujia, Zhejiang Province, China.

Paratype. NIGP171185: a partial specimen showing the apical region, from the type locality.

Diagnosis. Slender Auraeopirania with very fine, dense prostalia, a narrowed basal area and radiating basal spicules; a few enlarged marginalia interspersed with fine prostalia at apex.

Description. Two specimens known, both partly pyritised and oxidised; specimens differ in size, and in the region of the sponge that is preserved, but skeletal similarities are such that the second specimen is almost certainly of the same species and is assumed to be so for this description.

Overall form tall cylindrical, up to at least 10 $\mathrm{mm}$ wide (7 $\mathrm{mm}$ in holotype) and more than three times higher than wide (Figure 5.1, 5.2). Body wall largely obscured by skeleton but based on spicule density distribution, body width perhaps half of visible width. Body wall probably very thin, showing no significant relief or visible margin, despite pyritisation of skeleton. Apex (Figure 5.5, 5.6) narrowed by $10 \%-20 \%$ in uppermost few millimetres, but rest of body effectively cylindrical until extreme base (described below).

Skeleton dominantly composed of very fine (0.02 mm-wide) monaxons radiating almost perpendicularly from the body wall and extending up to $2.5 \mathrm{~mm}$. Holotype shows systematic deflection of distal parts of spicules towards base (Figure
5.3), but this may be biostratinomic; in paratype, prostalia of the apical region project essentially perpendicularly to the wall (Figure 5.6). Holotype shows strong median parting of prostalia (Figure 5.1-5.3) resulting from compression of spicules to either side (also confirming that most of the spicule projected out from the soft tissues, rather than being embedded). Aside from downwards flexure, spicules are mostly straight. Around apex (seen in paratype; Figure 5.6), dense wall of fine spicules is supplemented by sparse palisade of coarse monaxons with broad but poorly preserved bases, extending vertically or slightly divergently from oscular margin. These marginalia extend up to 2-3 $\mathrm{mm}$ beyond fine spicule array, with maximum observed length $3 \mathrm{~mm}$; all are straight.

Basal region of holotype (Fig. 5.4) distinctive, with lowest $3 \mathrm{~mm}$ of body wall abruptly narrowed, then expanded slightly into bulbous structure, 1 $\mathrm{mm}$ wide. This basal section supports radial array of straight, robust, but relatively short basalia up to $3 \mathrm{~mm}$ long. Entire basal section is slightly separated from the rest of the sponge, implying rigidity or structural coherence and relative weakness of body wall immediately above it.

Remarks. This species is distinctive in several respects, although it shares the structure of the basal region with $A$. pinwyddeni gen. et sp. nov. The overall form resembles the type species, $A$. auraeum (Botting, 2007), but is substantially more elongate, with finer prostalia and lacks the curtainlike basal spicule array. The array of sparse, robust marginalia is not seen in most other species and is not as pronounced as where it occurs in the diminutive $A$. pykitia gen. et sp. nov. Despite the limited material, therefore, $A$. sciurucauda gen. et sp. nov. is clearly distinguishable from all other described taxa.

\section{Auraeopirania pykitia sp. nov. Figure 6}

\section{zoobank.org/283E70EA-5A6A-498A-9F73-E8D2A7D81617}

Name. From the Scots word pykit, meaning spiky. Diagnosis. Small Auraeopirania up to approximately $10 \mathrm{~mm}$ long, with dense wall of upwardlydivergent, very fine prostalia and prominent array of distinct, much more robust marginalia.

Holotype. GLAHM 163227, a largely complete specimen on a slab with articulated odontopleurid trilobites, from the lower Sandbian (Baltoniodus gerdae Conodont Subzone) of Laggan and Dalfask Quarry, Girvan, UK.

Paratypes. GLAHM 163228/1 and GLAHM 163228/2, two specimens on one slab: (1) a nearcomplete but weakly preserved specimen, 

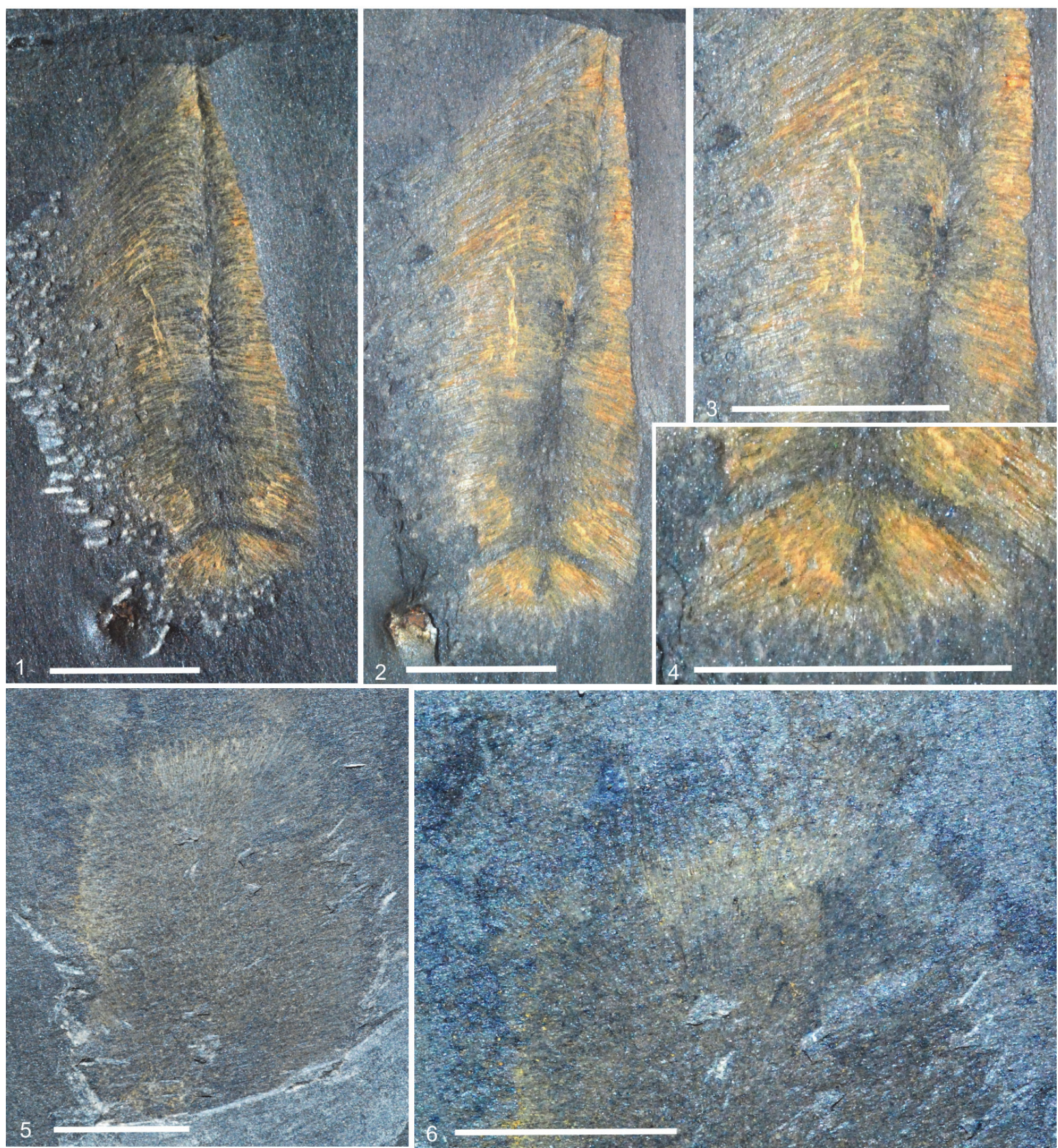

FIGURE 5. Auraeopirania sciurucauda gen. et sp. nov.; 1-4, holotype NIGP171184; 1, overall view, photographed dry; 2 , the same, under water; 3 , magnification of central region showing prostalia array; 4 , magnification of basal region with radiating spicule tuft. 5-6, paratype NIGP171185, showing apical region; 5, overall view, photographed dry (contrast strongly enhanced); 6 , detail of apex photographed under water to highlight marginal prostalia. Scale bars 5 $\mathrm{mm}$.

unweathered and (2) a similar but weathered and partly abraded specimen at the opposite end of the slab.

Description. The three specimens show contrasting features; holotype (Figure 6.1) with semi-pyritised spicules, the specimen bent against a trilobite exoskeleton, and partially exposed; paratypes both mostly straight, partly exposed, with one unweathered (Figure 6.7) and one largely weathered (Figure 6.2). This description combines information from all specimens. 


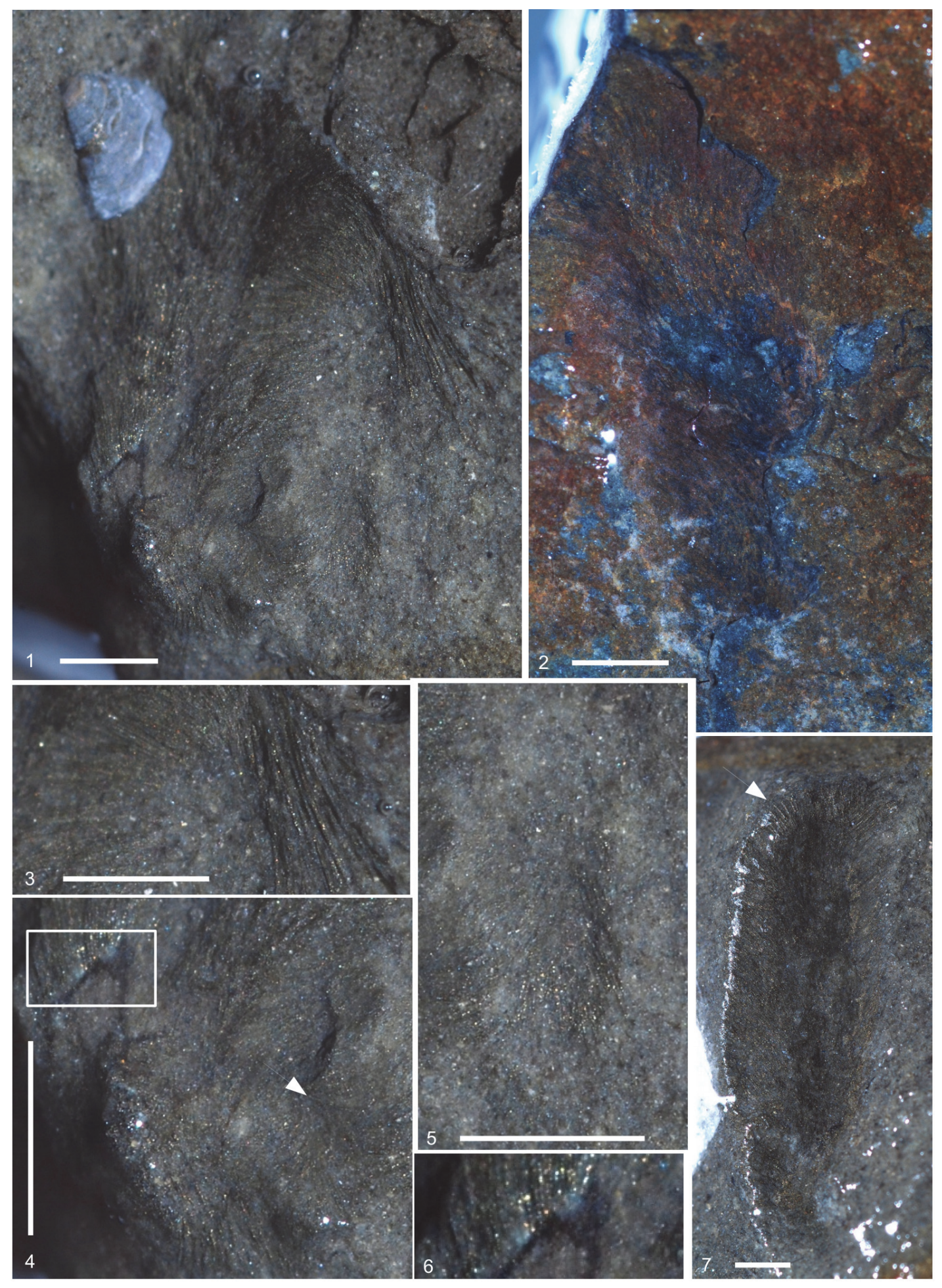

FIGURE 6. Auraeopirania pykitia gen. et sp. nov., from the Upper Ordovician of Dalfask, Scotland. 1, 3-6, holotype GLAHM 163227; 1, overall view of specimen distorted apically where in contact with Diacanthaspis trippi specimen; 3 , magnification of upper part with contrast between lateral prostalia (left) and robust marginalia (upper right); 4, magnification of basal region, including possible branch or bud at lower right (plumose spicule array, arrowed), second possible branch along lower margin of slab, and area magnified in 6 (box); 5 , isolated partial branch adjacent to the holotype; 6 , detail of body wall in cross section, with dense array of pyritised lateral prostalia; 2, paratype GLAHM $163228 / 1$, overall view of weathered specimen; 7, paratype GLAHM 163228/2, overall view of pyritised specimen with coarser apical marginalia (arrowed) amongst dense lateral prostalia. Scale bars equal $1 \mathrm{~mm}$. 
Holotype approximately $7 \mathrm{~mm}$ long but distorted, with apex strongly bent and base not seen. Width of body approximately $0.7 \mathrm{~mm}$ in middle part, but full spicule array over $3 \mathrm{~mm}$ wide at same point; no obvious changes in width visible in limited part visible. Paratype (e) at least $10 \mathrm{~mm}$ long, the base and extreme apex not seen (Figure 6.7); prostalia are swept in one direction with body margins unclear but spicule array $3 \mathrm{~mm}$ wide $(2 \mathrm{~mm}$ at lowest exposed part). Paratype (f) the least well preserved, $8.5 \mathrm{~mm}$ long (apex not seen but base visible), with maximum observed width $2.5 \mathrm{~mm}$ (margins of body not visible) but sides of spicule array not exposed; base approximately $1 \mathrm{~mm}$ wide, gradually widening upwards (Figure 6.2). Body wall appears to have been very thin (Figure 6.6).

Spicules mostly homogeneous, fine monaxons angled obliquely to the body wall (Figure 6.1, 6.3); angle varies from 30 to $70^{\circ}$ to the longitudinal axis, but often distorted locally and different on either side of the sponge. Lateral prostalia variable in length with maximum observed $3 \mathrm{~mm}$, and basal diameter $0.01-0.03 \mathrm{~mm}$. No obvious tapering of prostalia until near the apex, or basal expansion, but spicules are coarsely replaced by pyrite and preserve little fine detail.

Holotype (Figure 6.3) and unweathered paratype (Figure 6.7) show a distinct, coarser spicule type around the apex, forming marginalia that are interspersed among finer lateral prostalia and extend up to $4 \mathrm{~mm}$. Width substantially larger than lateral prostalia, typically $0.05 \mathrm{~mm}$. Marginalia show greater rigidity than lateral prostalia in deformed part of holotype.

No obvious evidence for wall-parallel spicules, but if present these would be largely obscured by extremely dense array of lateral prostalia. Basal area indistinct but visible in weathered paratype as partly-exposed, rounded region with spicules apparently radiating.

Holotype shows either branching or associated juveniles near to base (Figure 6.4), with one detached plumose section $1.5 \mathrm{~mm}$ long (Figure 6.5), and another $1 \mathrm{~mm}$-long section apparently continuous with the main sponge. At the edge of the block, the base of the main sponge also appears to show a strongly divergent array of spicules, $1.5 \mathrm{~mm}$ long, which may indicate branching of the main sponge body (Figure 6.4). However, all the observed features could be interpreted as distortion of a normal, somewhat tufted basal part of the sponge, or as associated juvenile sponges, and branching cannot be confirmed in this material.
Remarks. The two specimens are small, partially preserved (one weathered, one not), and taphonomically difficult due to the differences between weathered and unweathered states. Nonetheless, they preserve enough information to confirm significant morphological differences from other described taxa and allow a diagnosis. The narrow body and dense array of long, fine prostalia refer the species to Auraeopirania gen. nov., and it differs from all other species described to date in the presence of a clearly distinct class of coarse marginalia. In addition, the fineness and density of the prostalia is unusual even in this genus. The small size is also unusual, although it is close to that of the single specimen of $A$. pinwyddeni gen. et sp. nov.; however, some caution is needed because the three specimens are likely to have been preserved at effectively a single moment and may represent a single growth stage.

\section{Genus CANNAPIRANIA nov.}

\section{zoobank.org/897A30F3-C6B8-402C-A17B-F145DAFA74EF}

Name. After Latin canna, meaning reeds, referenced in the name of the type species due to the prominent marginalia.

Type species. Cannapirania canna sp. nov., from the upper Darriwilian Holothurian Bed (Llanfawr Mudstones Formation) of Wales; designated herein.

Diagnosis. Small, tubular piraniids (solitary or branched) with osculum not normally substantially narrowed, in some species surrounded by prominent, usually vertical marginalia; prostalia densely distributed, robust, typically angled at c. $30^{\circ}$ to the vertical axis and usually straight; prostalial bases may be rounded but not obviously open; finer monaxons either obvious and dense along entire body, or restricted to basal part.

Remarks. The diminutive nature, tubular body and consistent organisation of the prostalial spicules give this genus a characteristic appearance that is distinctive among piraniids. This is the most diverse of the piraniid genera, with three species now known, from Ordovician strata of Wales and China. The small size makes characterisation of prostalia bases difficult, but preservation suggests that the prostalia are effectively solid spicules, rather than partly hollow organic sclerites. Combined with the small size, this may be considered as reason to doubt assignment to the Piraniidae; however, all other aspects of the morphology support a close relationship to Pirania. In particular, the branching observed in C. vermiformis gen. et $\mathrm{sp}$. nov. is highly unusual among other early sponges, but is typical of the family; the basal morphology of 
the holotype of C. Ilanfawrensis (Botting, 2004, fig. $2 \mathrm{E}$ ) is suggestive of a broken branch here as well. The new species $C$. canna was chosen as the type species, as this is the best known.

Other species. Pirania llanfawrensis Botting, 2004, from the basal Sandbian Llanfawr Mudstones Formation of Llanfawr Quarry, Wales, and Cannapirania vermiformis sp. nov., from the latest Hirnantian Anji Biota of Zhejiang, China.

\section{Cannapirania canna sp. nov.}

\section{Figure 7}

zoobank.org/283E70EA-5A6A-498A-9F73-E8D2A7D81617

2015 Pirania sp. Muir and Botting, p. 187.

Name. Latin canna, reed or cane, after the densely-packed fringe of marginalia.

Holotype. NMW2019.25G.1, a complete specimen with partial pyritisation (oxidised), from the upper Darriwilian (Hustedograptus teretiusculus Biozone) Llanfawr Mudstones Formation ('Holothurian Bed' of Botting and Muir 2012) at Bach-y-Graig, near Llandrindod, Wales (UK grid reference SO07106102).

Paratype. NMW2019.25G.2, a second complete specimen with skeleton preserved as a compression with spicules in low relief; from the type locality.

Diagnosis. Small piraniid with dense array of short spicules between prostalia and with a dense vertical fringe of long marginalia.

Description. Elongate, tubular sponge, with body $9 \mathrm{~mm}$ long and apical width $1.3 \mathrm{~mm}$ in holotype (paratype $7 \mathrm{~mm}$ long and $1 \mathrm{~mm}$ wide). Basal $2 \mathrm{~mm}$ (approximately) apparently widened irregularly due to radiating fine spicules, but thereafter expands slowly from a minimum width of around $1 \mathrm{~mm}$ in the holotype (0.8 $\mathrm{mm}$ in paratype). Body straight or slightly curved.

Skeleton composed of three distinct spicule types: fine radiating monaxons, lateral prostalia and marginalia. Most obvious spicules are lateral prostalia (Figure 7.1, 7.2), densely distributed through full height of sponge (except basal part), oriented at $20-30^{\circ}$ to the sponge axis. Maximum observed length approximately $3 \mathrm{~mm}$, with basal diameter up to $0.05 \mathrm{~mm}$. Spicules taper evenly over length; extreme base are rounded or slightly expanded (Figure 7.5), but rarely visible.

Fine radiating monaxons are most clearly visible in basal region, but extend up most or all of the length of the body. Length of fine spicules in central part of body up to $1 \mathrm{~mm}$, and much finer than prostalia, with no obvious tapering or basal expansion. In basal part of sponge, spicules radiate in all directions (Figure 7.2), including both an even array, and localised projecting tufts (possibly biostratinomic). Above the basal area, spicules appear to parallel the prostalia as far as is visible.

Marginalia (Figure $7.3,7.4,7.6$ ) resemble lateral prostalia but slightly longer $(3.5 \mathrm{~mm}$ in holotype; truncated at $2 \mathrm{~mm}$ in paratype); basal diameter similar to prostalia in widest spicules, but generally somewhat narrower. Orientation parallel to sponge axis, or very slightly convergent, forming dense palisade. Palisade is not composed of single generation and size of spicule, but finer spicules are largely obscured by larger ones.

Remarks. The long, vertical marginalia appear to separate the species from the otherwise similar $C$. Ilanfawrensis (Botting, 2004) and from all other species known at this time. Although the type material of $C$. Ilanfawrensis lacks a clear definition of the apex, and it remains possible that significant marginalia are also present there but are obscured by rock breakage, there are also significant differences in the wider distribution of fine monaxons along the length of the body.

\section{Cannapirania vermiformis sp. nov. Figure 8}

zoobank.org/283E70EA-5A6A-498A-9F73-E8D2A7D81617

Name. Latin, meaning worm-like, referring to the appearance of the branched holotype.

Holotype. NIGP171186, from bed ZWK3 of the Wenchang Formation, Zhuwukou, Anji County, Zhejiang Province, China (coordinates $\left.30^{\circ} 30.507^{\prime} \mathrm{N}, \quad 119^{\circ} 22.712^{\prime} \mathrm{E}\right)$. Single branched specimen.

Diagnosis. Tubular Cannapirania with dense array of relatively fine prostalia that merge with slightly more robust marginalia in form and orientation; marginalia in some cases with rounded bases.

Description. Single specimen (Figure 8.1) consists of two branches joined at the base, each branch around $7 \mathrm{~mm}$ long (including marginalia). Body tubular, of roughly even diameter (c. $1 \mathrm{~mm}$ ) throughout length, except for somewhat narrowed apex of left branch. Body coarsely mineralised and weathered, such that wall thickness is unknown; however, near-complete flattening implies a thin wall with broad axial cavity. Body narrows abruptly to $0.2 \mathrm{~mm}$ at junction between branches.

Visible spicules are exclusively prostalia, projecting outwards at typically $20-40^{\circ}$ to the axis in lateral arrays. One branch shows disturbance of orientation in the lower part (probably due to transport), but typical arrangement apically. Spicules are mostly straight, with long curved spicules seen only in basal region. Lateral prostalia up to $2.5 \mathrm{~mm}$ long and $0.06 \mathrm{~mm}$ wide at base, tapering to $0.03 \mathrm{~mm}$ 

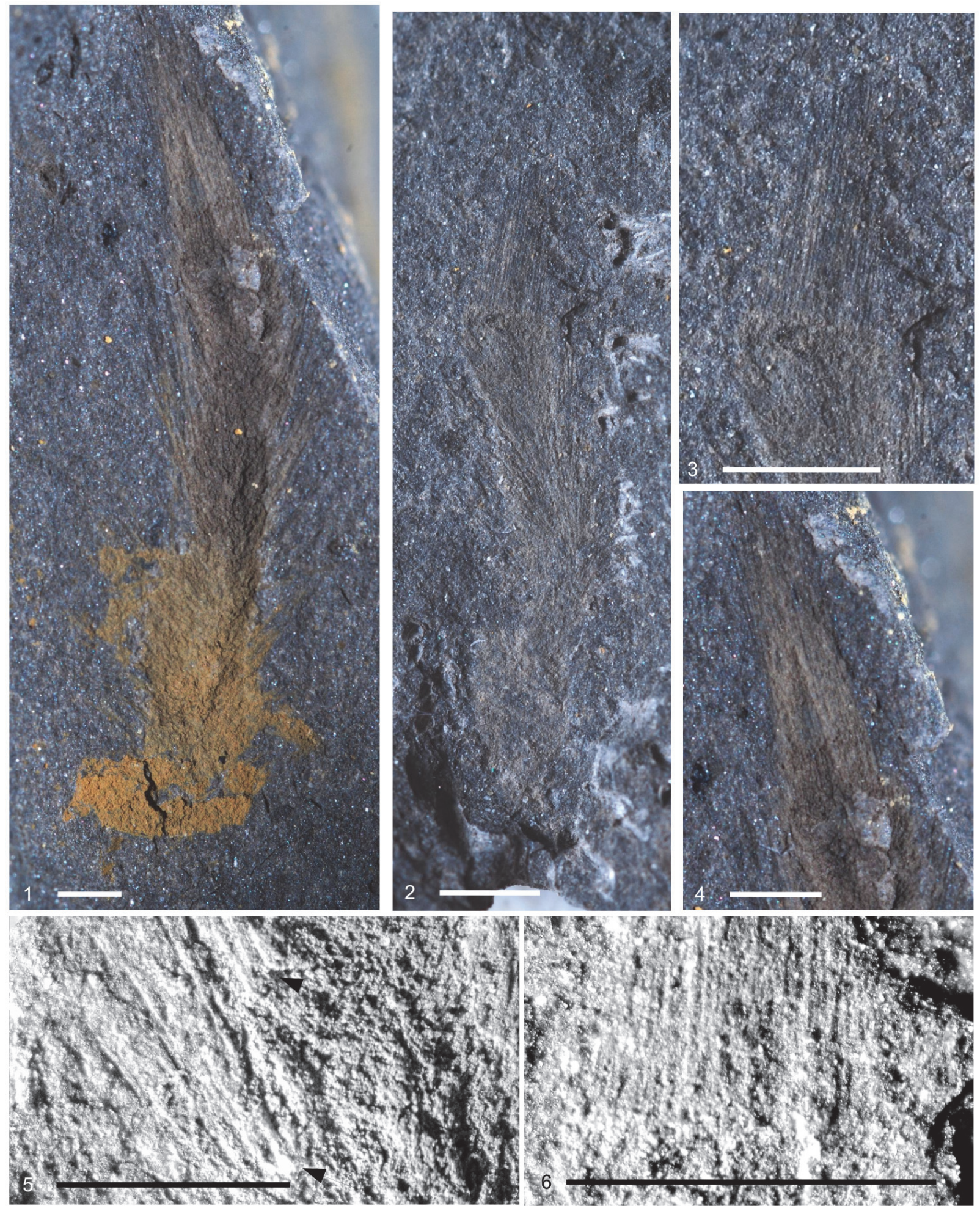

FIGURE 7. Cannapirania canna gen. et sp. nov., from the late Darriwilian $(H$. teretiusculus Biozone) Holothurian Bed fauna of Bach-y-Graig, Llandrindod, Wales. 1, 4, 5: holotype NMW2019.25G.1; 1, overall view of specimen with spicules largely replaced by iron oxides; 4, detail of apical region; 5, magnification of upper left lateral margin, showing rounded and occasionally expanded (tylotic; arrowed) prostalial bases. 2, 3, 6: paratype NMW2019.25G.2.; 2, overall view of specimen with spicules largely preserved as moulds with traces of siliceous minerals; 3 , detail of apical end including marginalia; 6 , magnification of base of marginalia, showing abrupt narrowing indicating stylose bases. Scale bars equal $1 \mathrm{~mm}$. 

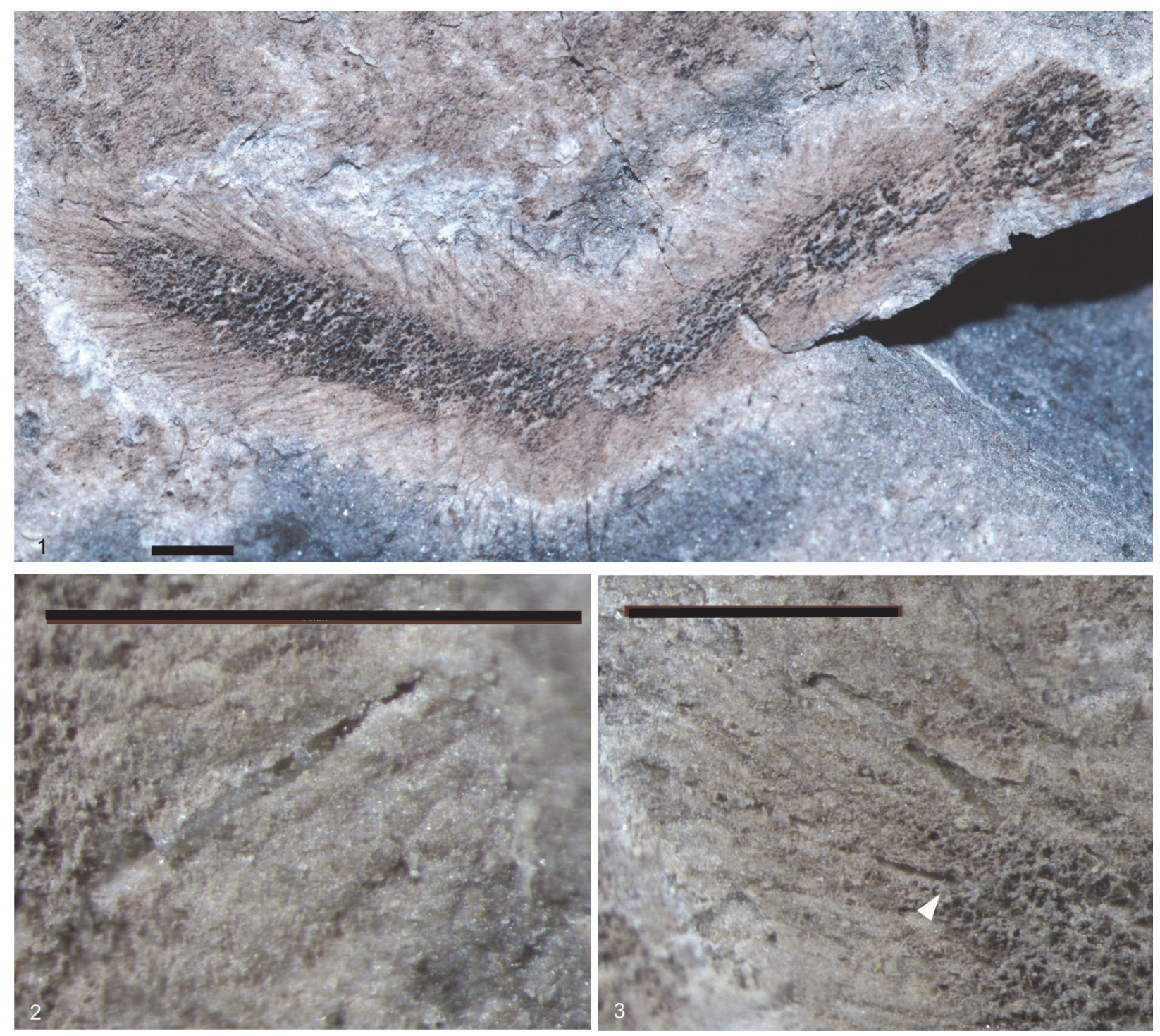

FIGURE 8. Cannapirania vermiformis gen. et sp. nov., from the Hirnantian Anji Biota of Zhejiang, China, holotype NIGP171186. 1, Overall view of branched specimen; 2, detail showing siliceous preservation of the largest spicules; 3 , detail showing rounded, tylotic base (arrowed) of marginal prostalia. Scale bars equal $1 \mathrm{~mm}$.

wide in the central part, and narrowing distally. Most prostalia around $1.5 \mathrm{~mm}$ long, or less, and proportionately narrower. Density of larger lateral prostalia is greater in the apical half of sponge, with weakly-preserved finer spicules dominating in lower part. Spicule bases usually unclear, except for marginalia (Figure 8.3).

Marginalia not strongly differentiated from lateral prostalia, and without sharp change in direction. Apices of spicules normally not visible due to rock breakage, but length appears similar to lateral prostalia. Several marginalia show clear bases, however (Figure 8.3), suggesting broader or more heavily mineralised than lateral spicules. Bases are rounded (styles), and in some cases appear slightly expanded (subtylostyles), up to $0.07 \mathrm{~mm}$ wide.

Around basal region of sponge, several long (more than $2 \mathrm{~mm}$ ), prominent spicules project at irregular angles and are slightly curved (Figure 8.1, centre, projecting downwards). Diameter appears normal (0.02-0.04 $\mathrm{mm}$ at mid-length), and curvature may be original rather than biostratinomic. Surrounding spicules appear to be abundant fine monaxons up to $1.5 \mathrm{~mm}$ wide, but weathering of dense overlapping array makes most individual spicules indistinct.

Spicules are mainly dissolved, but rare examples of the largest prostalia retain recrystallised silica and/or traces of pyritised axial canals (Figure 
8.2). No evidence for robust organic sheath or mineralogically distinct outer layer, but either could easily be disguised by recrystallisation of silica.

Remarks. The new species differs significantly from Cannapirania canna gen. et sp. nov. in that it lacks the strongly differentiated spicules around the osculum, which appears to be slightly narrowed. In most other respects, however, it conforms closely to the other species, including the concentration of coarse prostalia in the apical part, and a dense array of finer prostalia in the lower part. The prostalia in C. vermiformis gen. et sp. nov. are, however, denser and generally finer over most of the body. The transition to finer spicules basally is gradual, unlike in C. Ilanfawrensis, where the basal tuft is strongly differentiated.

The species is significant in suggesting a normally siliceous spicule composition for the genus. However, although there is no trace preserved of mineralogically distinct outer layers, or hollow interiors, this may be due to taphonomic loss. The morphology of the spicule bases, however, does support a rounded termination of a solid structure, at least for the marginalia; this is in contrast to the open-based, flexible 'sclerites' in Pirania muricata (Botting et al., 2013).

Genus PELLIPIRANIA gen. nov. zoobank.org/283E70EA-5A6A-498A-9F73-E8D2A7D81617

Name. From Latin, pellicia, meaning furry, in relation to the dense fur of fine spicules.

Type species. Pellipirania gloria sp. nov., designated here.

Diagnosis. Conico-cylindrical piraniids with dense, tufted skeleton of radiating monaxons, and long prostalia in apical region only.

Remarks. This genus is characterised particularly by a thicker, dense fur of radially directed fine spicules, with relatively sparse robust prostalia. This combination of spicules is similar to some of the earlier protomonaxonids, whereas many later piraniids reduced the number of fine spicules among the prostalia, or increased prostalial density and reduced their thickness, so that the distinction of prostalia from other spicules was obscured. It is unclear whether the fine spicules in Pellipirania were largely embedded within a soft-tissue wall or projected significantly from the surface.

\section{Pellipirania gloria sp. nov.}

Figure 9

zoobank.org/283E70EA-5A6A-498A-9F73-E8D2A7D81617

2016 piraniid A Botting, fig. 3F

Name. Latin for glory, as in the radiating rays around an icon's head, and also used for the rays of sunlight through clouds; after the prostalia radiating from the upper part of the sponge.

Diagnosis. As for genus.

Holotype. NMW2015.34G.27, a complete specimen from the Araneograptus murrayi Biozone (Tremadocian, Lower Ordovician) of the Fezouata Shale, locality 2008-3, near Zagora, Morocco [Lat. $30^{\circ} 29^{\prime} 38.688^{\prime \prime N}$, long. $05^{\circ} 53^{\prime} 12.12 " \mathrm{~W}$.]

Paratypes. NMW2015.34G.23, -25 and -26. Fragmentary and disarticulating material from the same locality.

Description. Information regarding the overall morphology is derived largely from the holotype (Figure 9.1); other specimens are fragmentary or disarticulating, but include additional details of spicule morphology and arrangement. Holotype 84 $\mathrm{mm}$ tall and maximum of $40 \mathrm{~mm}$ wide in upper third (as measured to outer edge of radiating dense spicule array; soft tissue wall may be hidden within this). Broadly rounded base, gradual widening through middle part and narrowing apically to 27mm-wide oscular margin; diameter of osculum itself not seen. Body wall appears irregular in thickness due to variable compression of spicule tufts and irregular mineralisation; thickness of soft tissue of wall unknown.

Skeleton with two major components: dominant radiating fine spicules (Figure 9.4), and apical prostalia (perhaps marginalia; Figure 9.2, 9.3). Radiating spicules difficult to measure in holotype (perhaps up to $10 \mathrm{~mm}$ long), but in disarticulating specimens, exceed $20 \mathrm{~mm}$ long, with diameter normally in the range $0.05-0.10 \mathrm{~mm}$. Fine spicules show no obvious taper, although they may be wider in the centre; no indication of expanded bases and presumed to be oxeas. Arrangement of spicules very dense; although the irregularity of the surface creates the appearance of discrete, closely spaced tufts of spicules (Figure 9.4), disarticulating material preserving spicule array in lateral view (visible most clearly in paratypes) suggest that spicules are distributed densely but evenly. The appearance of tufts is likely to result from biostratinomic distortion rather than biology and implies that the spicules project from the surface rather than being embedded in a thick wall that would preserve relative orientation better.

Prostalia (Figure 9.2, 9.3) radiate perpendicular to surface, but only in apical region, above the point of maximum width, and concentrated around oscular margin. Maximum length of prostalia in holotype exceeds $30 \mathrm{~mm}$, with visible base $0.2-0.4$ $\mathrm{mm}$ wide. Spicules appear to taper evenly to tip, but base embedded within radiating oxea array, 

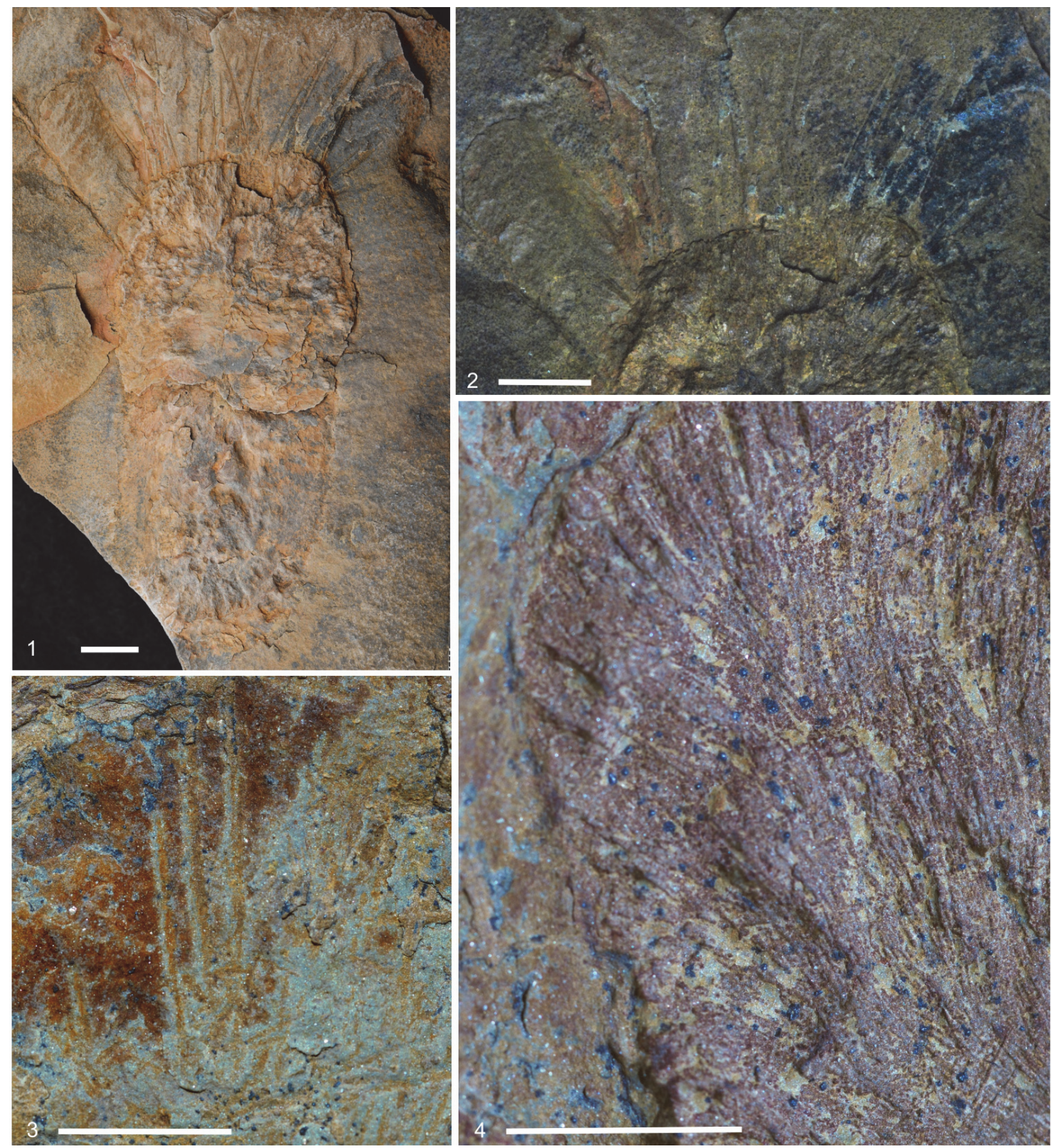

FIGURE 9. Pellipirania gloria gen. et sp. nov., from the Tremadocian Fezouata Biota of Morocco. 1, holotype NMW2015.34G.27, overall view, whitened with ammonium chloride; 2, apical region of holotype, not whitened and in low-angle light; 3, detail of prostalial spicules in paratype NMW2015.34G.26; 4, detail of fine, radially directed body wall spicules in holotype. Scale bars equal 1, 2: $10 \mathrm{~mm} ; 3,4: 5 \mathrm{~mm}$.

and difficult to characterise but appears abruptly rounded (therefore styles; Figure 9.4). Loose spicules on paratype slabs also appear to show rounded bases. basalia.

No obvious basal modifications or projecting
Remarks. The new species is highly distinct from all other described piraniids, with a much denser array of fine spicules, and much sparser and more localised distribution of prostalia. Given that the prostalia of piraniids have their evolutionary origin in the inosculating coarse spicules of Halichondrites and allies (Botting et al., 2013), the apical 
TABLE 1. Distribution of key characters (as currently known) across described piraniid species (except the poorly known A.? plasi) to aid taxonomic recognition. Taxa: P. m.: Pirania muricata; P. e.: Pirania? ericia; P. p.: Pirania? peregrinata; A. a.: Auraeopirania auraeum; A. s.: Auraeopirania sciurucauda; A. py.: Auraeopirania pykitia; A. p.: Auraeopirania pinwyddeni; C. I.: Cannapirania llanfawrensis; C. c.: Cannapirania canna; C. v.: Cannapirania vermiformis; P. g.: Pellipirania gloria.

\begin{tabular}{|c|c|c|c|c|c|c|c|c|c|c|c|}
\hline Character & P. $\mathrm{m}$. & P. e. & $P . p$. & A. a. & A. $s$. & A. $p$. & A. py & C. $I$. & C. c. & C. $v$. & P. g. \\
\hline Dermal sculpture & $x$ & & & & & & & & & & \\
\hline Narrowed osculum & $x$ & $x$ & $x$ & $x$ & $x$ & & & & & $(x)$ & \\
\hline Narrow tubular body & $x$ & $x$ & $x$ & $x$ & $x$ & $x$ & $x$ & $x$ & $x$ & $x$ & \\
\hline Body widens upwards & $x$ & $x$ & & & & & & & & & $x$ \\
\hline Clearly rounded prostalia bases & $x$ & & & & & $x$ & & $x$ & $x$ & $x$ & $x$ \\
\hline Open conical prostalia bases & $x$ & $x$ & & & & & & & & & \\
\hline Curtain-like basal tuft & & & $?$ & $x$ & & & & & & & \\
\hline Radiating basal array & & $x$ & $?$ & & $x$ & $x$ & & & & & \\
\hline Irregular basal tuft & $x$ & & & & & & $x ?$ & $x$ & $x$ & $x$ & \\
\hline No radiating fine diacts & & & $x$ & & & $x$ & & & & & \\
\hline $\begin{array}{l}\text { Extremely dense radiating fine } \\
\text { monaxons }\end{array}$ & & & & $x$ & $x$ & & $x$ & & & & $x$ \\
\hline $\begin{array}{l}\text { Prostalia not distinct from fine } \\
\text { monaxons }\end{array}$ & & & & $x$ & $x$ & & $x$ & & & & \\
\hline Branching & $x$ & $x$ & & & & & $x ?$ & $x ?$ & & $x$ & \\
\hline Distinct marginalia & & & & & & $\mathrm{x}$ & $\mathrm{x}$ & & $x$ & $\mathrm{x}$ & $\mathrm{x}$ \\
\hline
\end{tabular}

distribution must be considered a derived trait, together with the increased density of the fine monaxons.

\section{DISCUSSION}

\section{Phylogenetic Relationships}

The addition of multiple new species to the Piraniidae provides much greater detail about the evolution of characters within the group, summarised in Table 1. This both complicates the issue by showing significantly increased morphological diversity, and allows a more reasoned assessment of the sequence of character state changes. In order to polarise these changes, we follow Botting et al. (2013) in regarding the nearest related protomonaxonids to be Halichondrites and Lenica. Both were broadly conical (one tall, one more flattened) sponges with longitudinal to outwardly projecting spicules of two types: fine monaxons, and coarser, broad-based 'sclerites'. No specialised basalia or marginalia are present in these more basal forms. Finer spicules in Halichondrites appear to have been standard siliceous monaxons (Rigby and Collins, 2004), and probably also in an undescribed protomonaxonid from the early Cambrian Hetang Biota that has strongly differentiated conical sclerites (Botting et al., 2013, Figure 4.1, 4.3). The development of these sclerites into largely organic structures (as in Pirania and the Chancelloriidae) parallels the appearance of the enigmatic surface structure, a feature unknown from any other protomonaxonid (even in deposits with Burgess Shaletype preservation) and therefore undoubtedly derived. At least in some chancelloriids, the structure appears to be due to minute platelets (Cong et al., 2018) but its nature has not been confirmed in Pirania itself.

Although there are significant differences in the morphology, organisation and spicule structure of the four piraniid genera, there are sufficient points of similarity to imply that all are more closely related to each other than to other protomonaxonids. In particular, the tall body form with highly developed, regular prostalia differs from the irregular, slightly divergent arrangement of coarser spicules in Halichondrites. Furthermore, the branching present in Pirania and Cannapirania gen. nov. is not observed in any other protomonaxonid and is a highly derived feature that among Cambrian and Ordovician spiculate sponges is elsewhere seen only in early demosponges (Botting et al., 2013; Carrera, 2006) and in one reticulosan (Protoprisma Rigby and Collins, 2004). Additionally, the features separating the genera are to some extent gradational; for example, the narrowed osculum present in Pirania and Auraeopirania gen. nov. is also seen, to a lesser extent, in Cannapirania vermi- 


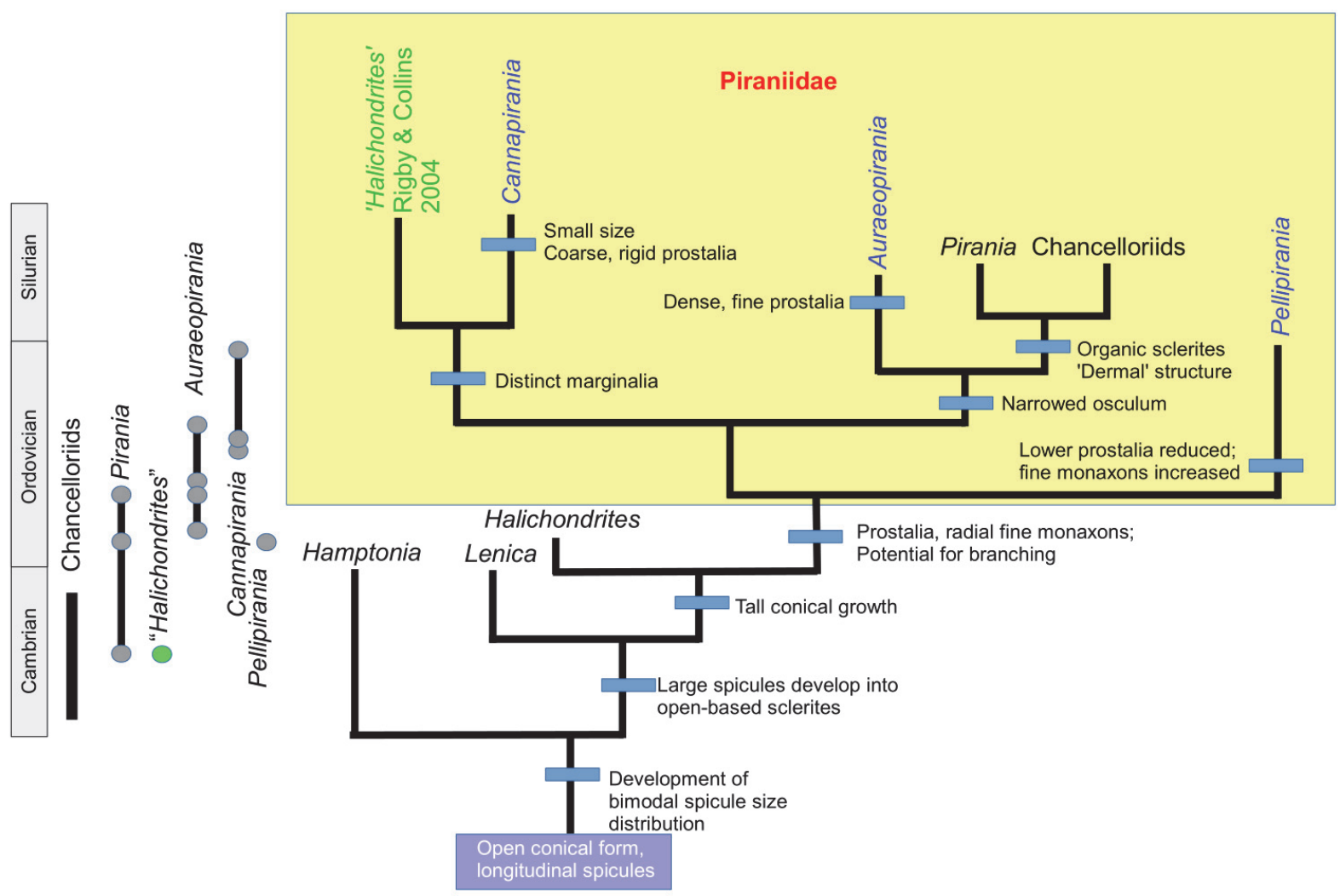

FIGURE 10. Schematic illustration of the evolution of the Piraniidae within the Protomonaxonida, with indications of what are here interpreted to be the most significant character transitions, combined with known stratigraphic ranges of taxa. Range of chancelloriids includes early appearance of distinctive sclerites, whereas other taxa are restricted to sites with exceptional preservation.

formis gen. et sp. nov.; this feature is therefore assumed to be morphologically plastic. Similarly, there is significant variation between piraniid taxa in the relative importance of fine monaxons between the prostalia.

The body form of more basal protomonaxonids in this lineage (Botting et al., 2013) is open conical to bowl-shaped, with a few genera (e.g. Halichondrites, as described by Walcott, 1920 and Rigby, 1986) becoming taller and thinner. All these, including the tall conical morphologies, lack a narrowed osculum; this character therefore developed within the Piraniidae, where present. In Hamptonia, Halichondrites and allies, there is a combination of large, sclerite-like spicules and a dense thatch of finer spicules. The reduction or loss of the finer spicules therefore also constitutes a derived trait.

In combination, these character polarities indicate the evolutionary outline in Figure 10. The most basal group is likely to be Pellipirania gen. nov., as it lacks derived features that are shared among other genera. The dense 'fur' of fine monaxons has been strongly developed, to a degree beyond that of any other lineage, and is presumably an apomorphy of the genus, combined with the coincident loss of prostalia over the lower part of the body. Cannapirania gen. nov. shows abundant robust prostalia combined with a variable proportion of fine monaxons that are in many species concentrated around the base and form an anchoring structure. The development of distinct marginalia is clear in the type species, and present also in C. vermiformis gen. et sp. nov. and cannot be excluded for C. Ilanfawrensis Botting, 2004; therefore, it is likely that this is a synapomorphy of the group, together with small size and near-tubular morphology. Auraeopirania gen. nov. is an equally distinct genus in which the prostalia are multiplied and lengthened, but are narrow, creating a thick corona of projecting spicules around the entire sponge. Where the osculum is narrowed, as in $A$. auraeum (Botting, 2007), this corona forms a near- 
complete halo surrounding the apex; where it is not, as appears to be the case in $A$. pinwyddeni gen. et sp. nov., the osculum is exposed. These spicules are generally not differentiated marginalia as seen in Cannapirania gen. nov., although some robust marginalia are also present in $A$. pykitia gen. et sp. nov. In Auraeopirania, the fine prostalia take over the role of the developed fine spicules seen in the basal part of Cannapirania, extending as a basal curtain in the type species and a simple radiating array in $A$. pinwyddeni.

The genus Pirania is now limited to species that show several derived characters, but most notably a reduction or loss of the fine monaxons (Walcott, 1920 noted their presence in the extreme base), combined with exaggeration of prostalia and a reduction in their abundance. The development of a distinctive dermal structure shared with chancelloriids is problematic to use as a diagnostic character, as it is only rarely preserved. In overall form, Pirania is relatively plesiomorphic, lacking any distinctive modifications beyond a slightly narrowed osculum and retaining a tall conical form with a narrow base. Assignment of the Afon Gam piraniid, P.? ericia sp. nov., is complicated by the presence of fine spicules parallel to the body wall. This is a feature absent from $P$. muricata, but seen in $A$. auraeum gen. et sp. nov. and in the basal groups such as Halichondrites. Otherwise, however, P.? ericia gen. et sp. nov. closely resembles P. muricata Walcott, 1920, in the preserved details, including branching. The basal structures of P.? ericia sp. nov. are non-diagnostic, and also consistent with Walcott's (1920) observations of the type species. Placement of this species within the lineage leading to $P$. muricata and chancelloriids is ambiguous, and it may represent a deeper point on that branch.

In addition to the taxa included here, other related fossils include a sponge named by Rigby and Collins (2004, pl. 16, fig. 6) as Halichondrites elissa Walcott, 1920. However, this material differs substantially from Halichondrites in having a dense array of fine prostalia (as in Auraeopirania gen. nov. and some Cannapirania gen. nov.), and it also appears to possess a dense fringe of long, distinct marginalia (limited to Cannapirania gen. nov.). It is broadly cylindrical but lacks a narrowed osculum, also indicating an assignment to Cannapirania gen. nov.; however, its large size is aberrant for the group (and probably plesiomorphic), and a sistergroup relationship to Cannapirania gen. nov. is most likely at this stage. Additional specimens or related species are required for full reconsideration of this form.

\section{Piraniid Palaeoecology}

The record of piraniids is extremely incomplete, partly because their skeletons are composed of unfused spicules that disarticulate rapidly after death, requiring conditions of exceptional preservation to produce recognisable fossils (see Botting and Muir, 2018, and references therein). This is typical of most early sponges, but piraniids are also generally scarce where they occur. In the Greater Phyllopod Bed of the Burgess Shale, Pirania muricata comprises $0.38 \%$ of the total fauna (Caron and Jackson, 2008), although it is more common at some other sites. In the Burgess Shale Tulip Beds, it is reasonably common but always found as isolated individuals (O'Brien and Caron, 2016). This pattern is confirmed in the Fezouata Biota, where Auraeopirania auraeum gen. et sp. nov. is unusual in being widespread but rare where it occurs, in contrast to the short-lived but dense populations typical of other sponges in the deposit (Botting 2007, 2016). This pattern was suggested (Botting 2016) to indicate a K-selected reproductive strategy, which generally favours low but relatively stable population densities. The other known occurrences of piraniid species currently consist of single specimens (Llanfallteg Biota, Pirania? peregrinata from Liujia and Anji Biota), two specimens (Holothurian Bed, Auraeopirania sciurucauda from Liujia, Llanfawr Quarries and Afon Gam Biota) or three (Dalfask Quarry, and Pellipirania gloria gen. et sp. nov., from the Fezouata Biota); from some of these sites, hundreds or thousands of other articulated sponges have been collected (e.g., Botting et al., 2015, 2017). Life rarity, therefore, seems to be a genuine factor responsible for the scarcity of piraniid fossils.

\section{Spatial and Temporal Distribution}

Allowing for the incomplete record, some unexpected patterns are visible in piraniid distribution. In Cambrian faunas, piraniids are so far limited to the Burgess Shale of Canada, represented by Pirania itself and the specimen assigned by Rigby and Collins (2004) to Halichondrites elissa. Piraniids exhibit a large geographic spread in the Ordovician, occurring in both equatorial and polar areas during the Early Ordovician and equatorial to high-latitude regions during the Middle-Late Ordovician (Figure 1). The only regions from which three genera are known are Avalonia (Wales) and South China (Zhejiang), but all piraniid records 
there are Ordovician (although no diverse Cambrian sponge faunas are yet known from Wales). Morocco contains two piraniid genera, including the only known record of Pellipirania gen. nov. Auraeopirania gen. nov. is currently the most widespread genus, with species in Morocco, Wales, Scotland (Laurentia), China and probably Bohemia; all of these records are Ordovician. Pirania itself is currently restricted to Canada (Cambrian) and Wales (Lower to Middle Ordovician). Cannapirania gen. nov., in contrast, is limited to the Middle and Upper Ordovician of Wales and China.

In terms of temporal distribution, Pirania has a range of middle Cambrian to Early Ordovician (Floian); Pellipirania is known only from the Early Ordovician (Tremadocian); Auraeopirania has a range of Early Ordovician to early Late Ordovician; and Cannapirania is known from the latest Middle Ordovician to the latest Ordovician (Figure 1.1). Overall, the first occurrences of the genera are in reverse order to the inferred evolutionary sequence (Figure 10). This apparent problem is negated by the phylogenetically early-branching specimen erroneously assigned to Halichondrites elissa by Rigby and Collins (2004). The absence of early examples of the earlier piraniid branches (or other taxa sharing plesiomorphic characters) is probably best explained as due to the natural rarity of these taxa and incomplete sampling. A recent study of generic distribution of Cambrian and Ordovician spiculate sponges (Botting and Muir 2019) indicates very wide dispersal of Cambrian sponge genera, with widely-distributed Ordovician genera being limited to those that had originated during the Cambrian; Ordovician evolutionary patterns appear to have been dominated by localised endemic diversification. Following this pattern, at least the new genera Cannapirania and Auraeopirania are likely to have diversified and become widespread during the Cambrian. The lack of Cambrian records suggests that they may have inhabited different environments to those typically represented by the Burgess Shale-type faunas.

\section{Palaeoenvironments}

There are now 12 species assigned to the Piraniidae, all except the type species ( $P$. muricata Walcott, 1920, from the Burgess Shale) from Ordovician deposits. These deposits include a wide range of water depths, from the storm-influenced deep shelf facies in the Fezouata Biota to basinal mudstones in the Anji Biota. Although water depth is very difficult to assess quantitatively for deposits formed below the shallower zones, relative depth can often be assessed on the basis of associated faunas, including such factors as eye development in trilobites and presence of deep pelagic taxa such as cyclopygids (Fortey and Owens, 1987). When this approach is applied to the piraniids, a striking trend emerges of generally smaller size in deeper water (Figure 11.1). Despite the limitations of low sample sizes per species and uncertainty over water depths of deeper deposits, each genus shows the same general trend.

No piraniids are yet known from sediments deposited at normal wave base or above, but there is an even distribution out to the deepest deposits represented. The smallest species is Cannapirania vermiformis gen. et sp. nov., from the Anji Biota (Botting et al., 2017), which is hosted in a basinal mudstone within a turbiditic sequence, and may have extended to several hundred metres water depth. The next deepest and smallest is Auraeopirania pinwyddeni sp. nov. (Llanfallteg Biota), although a very similar atheloptic assemblage of associated trilobites (Placoparia, cyclopygids) is recorded for the substantially larger $A$ ? plasi Pribyl, 1947. The depth of the Liujia locality is the most difficult to assess, as it is a slope-basin graptolitic fauna in dark to greenish grey mudstones with little other benthos-presumably due to low benthic oxygenation. The depth position inferred (around $170 \mathrm{~m}$ ) is in the centre of a large possible range in either direction; although it lies well below the shallow carbonate platform level, there is little constraint on the maximum depth, and no useful trilobite or brachiopod assemblage. However, protomonaxonid-dominated Ordovician faunas from Wales, UK (Muir and Botting, 2015), are concentrated around storm wave base rather than in deeper environments (where reticulosans dominate), and so a shallower depth appears more likely than a deeper one. Without equivalent data for South China, however, this remains uncertain. The relative depths of the shallower deposits are more confidently assigned; for details see the relevant descriptions.

An inverse size-depth relationship of sponges is unusual, with sponges typically growing larger with depth, at least in shallow environments (e.g. Mercado-Molina and Yoshioka, 2009). The same should be expected in deeper facies also, given that below the storm wave base structural support differences become insignificant, and the less the water movement the greater the feeding advantage given by height. Another factor potentially affecting size is food supply, but in the deepest-water assemblages with the smallest piraniids (Anji Biota 

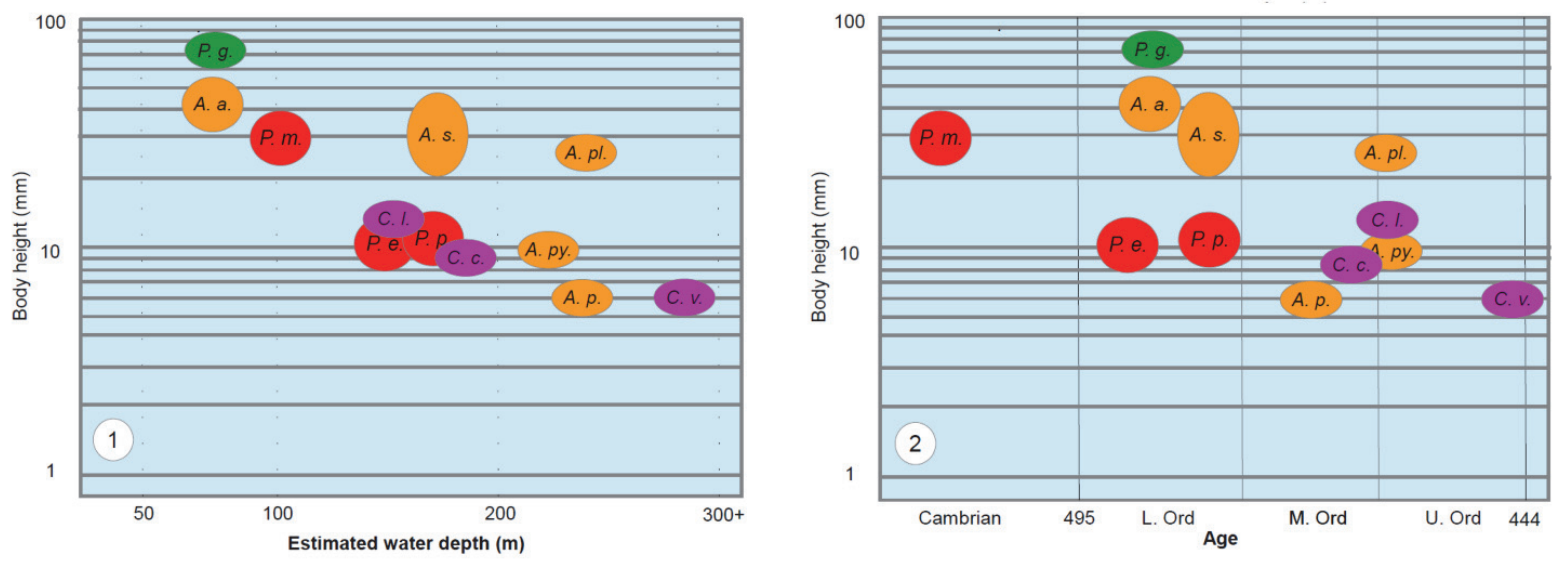

FIGURE 11. Correlation of body size of known piraniids against: 1, estimated water depth; 2 , stratigraphic age of the respective deposits. Taxa: P. m.: Pirania muricata; P. e.: Pirania? ericia; P. p.: Pirania? peregrinata; A. a.: Auraeopirania auraeum; A. s.: Auraeopirania sciurucauda; A. pl.: Auraeopirania? plasi; A. py.: Auraeopirania pykitia; A. p.: Auraeopirania pinwyddeni; C. I.: Cannapirania Ilanfawrensis; C. c.: Cannapirania canna; C. v.: Cannapirania vermiformis; P. g.: Pellipirania gloria.

and Llanfallteg Biota), these sponges are among the smallest of a wide range of other sponge taxa, some of which reached substantial sizes in excess of $10 \mathrm{~cm}$ tall (Botting et al., 2017; pers. obs.). Food limitation therefore seems not to have been a constraint, unless they were out-competed by more efficient pumping in co-occurring sponges that evolved within the deeper-water habitats. This is possible given the early-branching origin of protomonaxonids (Botting and Muir, 2018) and the contemporary appearance of more derived lineages such as crown-group demosponges and hexactinellids, and specialisation of particle uptake (e.g., McMurray et al., 2016).

In addition to the depth profile, plotting piraniid size against stratigraphic age gives a similar (though less constrained) trend towards decreasing size (Figure 11.2). This further implies that, in general, the younger occurrences tend to be in deeper water, although this is not true for sponge faunas as a whole. The pattern suggests gradual retreat to deeper-water environments, and this is consistent with the hypothesis above, with piraniids being progressively outcompeted by more derived sponge lineages with more efficient filtering capabilities, preventing them from developing large size as part of later ecosystems.

\section{CONCLUSIONS}

The Pirania complex of protomonaxonid sponges has until now been regarded as a simple continuum of taxa, with little regard for internal relationships, although recent inferences that they represent the ancestors of chancelloriids (Botting and Muir, 2018) have imbued the group with more significance. New material allows patterns of consistent morphology to be clarified, resulting in subdivision of the group into four genera (Pirania Walcott, 1920, Auraeopirania gen. nov., Cannapirania gen. nov. and Pellipirania gen. nov.). Of these, only Pirania is currently known from Cambrian strata. However, character polarisation by comparison with other protomonaxonids allows the known species to be placed into a plausible evolutionary sequence, and this implies that much of the piraniid record remains unknown. The genera likely diversified (at least in part) during the early to middle Cambrian, and the family must have been widespread in the Cambrian and earliest Ordovician; in later times, the group appears to have been forced progressively offshore, with a trend towards reduced size. One new occurrence, from the Hirnantian Anji Biota of China, implies that the piraniids survived the end-Ordovician Mass Extinction, at least locally, although no Silurian examples are yet known.

\section{ACKNOWLEDGEMENTS}

Research in China was supported by grants from the Chinese Academy of Sciences (CAS, grant nos. XDB26000000, XDB10010100) and the Ministry of Science and Technology of China (no. 
2013FY111000, 2017ZX05036-001-004) to ZYD. JPB's and LAM's work in Nanjing were funded by CAS President's International Fellowship Initiative (no. 2016VEB006 to JPB, no. 2018VCB0014 to LAM). Fieldwork in North Wales was supported by the National Geographic Society's Committee for Research and Exploration (\#9063-12). We are grateful to many people for assistance on fieldwork in Wales (N. Owen, C. Upton, T. Ormrod, N. Jordan) and China (M. Xuan, W. Longwu, Y. Guohua), and for donating material (C. Connolly, Llanfallteg Biota; P. Van Roy, F. Biota). Thanks to R. Vodrážka (Czech Geological Survey) for bringing Pirania plasi to our attention and to N. Clark (Hunterian Museum, Glasgow) for arranging access to the Scottish material. We are grateful for the comments from two anonymous referees that improved the manuscript. This is a contribution to IGCP project 653 (The Onset of the Great Ordovician Biodiversification Event).

\section{REFERENCES}

Bergström, S.M. 1990. Biostratigraphic and biogeographic significance of Middle and Upper Ordovician conodonts in the Girvan succession south-west Scotland. Courier Forschunginstitut Senckenberg, 118:1-43.

Bergström, S.M., Chen, X., Gutierrez-Marco, J.C., and Dronov, A. 2009. The new chronostratigraphic classification of the Ordovician System and its relations to major regional series and stages and to $\delta^{13} \mathrm{C}$ chemostratigraphy. Lethaia, 42:97-107. https://doi.org/ 10.1111/j.1502-3931.2008.00136.x

Botting, J.P. 2004. An exceptional Caradoc sponge fauna from the Llanfawr Quarries, central Wales, and phylogenetic implications. Journal of Systematic Palaeontology, 2:31-63. https:// doi.org/10.1017/S147720190300110X

Botting, J.P. 2007. 'Cambrian' demosponges in the Ordovician of Morocco: insights into the early evolutionary history of sponges. Geobios, 40:737-748. https://doi.org/10.1016/ j.geobios.2007.02.006

Botting, J.P. 2016. Diversity and ecology of sponges in the Early Ordovician Fezouata Biota, Morocco. Palaeogeography, Palaeoclimatology, Palaeoecology, 460:75-86. https://doi.org/ 10.1016/j.palaeo.2016.05.018

Botting, J.P. and Muir, L.A. 2012. Fauna and ecology of the Holothurian Bed, Llandrindod, Wales, UK (Darriwilian, Middle Ordovician), and the oldest articulated holothurian. Palaeontologia Electronica, 15.1.9A:1-28. https://doi.org/10.26879/272

Botting, J.P. and Muir, L.A. 2014. First post-Cambrian records of the reticulosan sponges Valospongia and Hintzespongia from the late Tremadocian of North Wales. Acta Palaeontologica Polonica, 59:241-252.

Botting, J.P. and Muir, L.A. 2018. The early evolution of sponges: a review and phylogenetic framework. Palaeoworld, 27:1-29. https://doi.org/10.1016/j.palwor.2017.07.001

Botting, J.P. and Muir, L.A. 2019. Dispersal and endemic diversification: differences in nonlithistid spiculate sponge faunas between the Cambrian Explosion and the GOBE. Palaeoworld, 28:24-36. https://doi.org/10.1016/j.palwor.2018.03.002

Botting, J.P. and Zhang, Y. 2013. A new leptomitid-like sponge from the Early Ordovician of China with heteractinid spicules. Bulletin of Geosciences, 88:207-217. https://doi.org/ 10.3140/bull.geosci.1361

Botting, J.P., Muir, L.A., and Lin, J.-P., 2013. Relationships of the Cambrian Protomonaxonida (Porifera). Palaeontologia Electronica, 16.2.9A:1-23. https://doi.org/10.26879/339

Botting, J.P., Muir, L. A., Jordan, N., and Upton, C. 2015. An Ordovician variation on Burgess Shale-type biotas. Scientific Reports, 5(9947):1-11. https://doi.org/10.1038/srep09947

Botting, J.P., Muir, L. A., Zhang Y., Ma X., Ma, J., Wang, L., Zhang, J., Song, Y., and Fang, X. 2017. Flourishing sponge-based ecosystems after the end-Ordovician mass extinction. Current Biology, 27:556-562. https://doi.org/10.1016/j.cub.2016.12.061

Botting, J.P, Zhang, Y and Muir, L.A. 2018. A candidate stem-group rossellid (Porifera, Hexactinellida) from the latest Ordovician Anji Biota, China. Bulletin of Geosciences, 93:275285. 
Bulman, O.M.B. 1944-47. A monograph of the Caradoc (Balclatchie) graptolies from the limestones in the Laggan Burn, Ayrshire. Monographs of the Palaeontographical Society, 98(430):1-42; 99(433):43-58; 101(439):i-xi, 59-78.

Caron, J.-B. and Jackson, D.A. 2008. Paleoecology of the Greater Phyllopod Bed community, Burgess Shale. Palaeogeography, Palaeoclimatology, Palaeoecology, 258:222-256. https:// doi.org/10.1016/j.palaeo.2007.05.023

Carrera, M.G. 2006. The new genus Multispongia (Porifera) from the Lower Ordovician limestones of the Argentine Precordillera. Ameghiniana, 43(2):493-498.

Cong, P.Y., Harvey, T.H.P., Williams, M., Siveter, D.J., Siveter, D.J., Gabbott, S.E., Li, Y.-J., Wei, F., and Hou, X.-G. 2018. Naked chancelloriids from the lower Cambrian of China show evidence for sponge-type growth. Proceedings of the Royal Society B, 285:20180296. https:/ /doi.org/10.1098/rspb.2018.0296

De Laubenfels, M.W. 1955. Porifera, p. E21-E112. In Moore, R.C. (ed.), Treatise on Invertebrate Paleontology, Part E. Geological Society of America and University of Kansas Press, Lawrence.

Fatka, O. and Budil, P. 2014. Sheltered gregarious behavior of Middle Ordovician harpetid trilobites. Palaios, 29:495-500. https://doi.org/10.2110/palo.2013.031

Finks, R.M. and Rigby, J.K. 2004. Paleozoic demosponges, p. 9-171. In Kaesler, R.L. (ed.), Treatise on Invertebrate Paleontology, Part E, Porifera (revised), vol. 3. Geological Society of America and University of Kansas, Boulder, Colorado and Lawrence, Kansas.

Fortey, R.A. and Owens, R.M. 1987. The Arenig Series in South Wales. Bulletin of the British Museum Natural History (Geology), 41:69-307.

Grant, R.E. 1836. Animal kingdom, p. 107-118. In Todd, R.B. (ed.), The Cyclopedia of Anatomy and Physiology. Gilbert and Piper, London.

Harper, D.A.T. and Owen, A.W. 1986. A shelly biofacies from the graptolitic mudstones of the Lower Balclatchie Group (Lower Caradoc) near Laggan, Girvan District. Scottish Journal of Geology, 22:271-283. https://doi.org/10.1144/sjg22020271

Hearing, T.W., Legg, D.L., Botting, J.P., Muir, L.A., McDermott, P., Faulkner, S., Taylor, A., and Brasier, M.D. 2016. Survival of Burgess Shale-type animals in a Middle Ordovician deepwater setting. Journal of the Geological Society, 174:628-633. https://doi.org/10.1144/ jgs2015-131

Ingham, J.K. 2000. Scotland: the Midland Valley Terrane-Girvan, p. 43-47. In Fortey, R.A., Harper, D.A.T., Ingham, J.K., Owen, A.W., Parkes, M.A., Rushton, A.W.A., and Woodcock, N.H. (eds.), A Revised Correlation of Ordovician Rocks of the British Isles. Geological Society of London Special report no. 24.

Martin, E.L.O., Pittet, B., Gutiérrez-Marco, J.-C., Vannier, J., El Hariri, K., Lerosey-Aubril, R., Masrour, M., Nowak, H., Servais, T., Vandenbroucke, T.R.A., Van Roy, P., Vaucher, R., and Lefebvre, B. 2016. The Lower Ordovician Fezouata Konservat-Lagerstätte from Morocco: age, environment and evolutionary perspectives. Gondwana Research, 34:274-283. https:// doi.org/10.1016/j.gr.2015.03.009

McMurray, S.E., Johnson, Z.I., Hunt, D.E., Pawlik, J.R., and Finelli, C.M. 2016. Selective feeding by the giant barrel sponge enhances foraging efficiency. Limnology and Oceanography, 61:1271-1286. https://doi.org/10.1002/Ino.10287

Mercado-Molina, A.E. and Yoshioka, P.M. 2009. Relationships between water motion and sizespecific survivorship and growth of the demosponge Amphimedon compressa. Journal of Experimental Marine Biology and Ecology, 375:51-56. https://doi.org/10.1016/ j.jembe.2009.05.003

Muir, L.A. and Botting, J.P., 2015. An outline of the distribution and diversity of Porifera in the Ordovician Builth Inlier (Wales, UK). Palaeoworld, 24:176-190. https://doi.org/10.1016/ j.palwor.2014.11.003

O'Brien, L.J. and Caron, J.-B. 2016. Paleocommunity analysis of the Burgess Shale Tulip Beds, Mount Stephen, British Columbia: comparison with the Walcott Quarry and implications for community variation in the Burgess Shale. Paleobiology, 42:27-53. https://doi.org/10.1017/ pab.2015.17

Přibyl, A. 1947. O rodu Pirania Walcott (Silicispongiae) z ceskeho ordoviku. Vĕstník Státního geologického ústavu, 22:363-370. [in Czech with English summary]. 
Rahman, I. A., Stewart, S.E., and Zamora, S. 2015. The youngest ctenocystoids from the Upper Ordovician of the United Kingdom and the evolution of the bilateral body plan in echinoderms. Acta Palontologica Polonica, 60:39-48. https://doi.org/10.4202/ app.00048.2013

Rigby, J.K. 1971. Sponges of the Ordovician Cat Head Member, Lake Winnipeg, Manitoba. Geological Survey of Canada Bulletin, 202:35-76.

Rigby, J.K. 1986. Sponges of the Burgess Shale (Middle Cambrian) British Columbia. Palaeontographica Canadiana, 2:1-105.

Rigby, J.K. and Collins, D. 2004. Sponges of the Middle Cambrian Burgess and Stephen Shale Formations, British Columbia. Royal Ontario Museum Contributions in Science, 1:1-164.

Saleh, F., Candela, Y., Harper, D.A.T., Polechová, M., Lefebvre, B., and Pittet, B. 2018. Storminduced community dynamics in the Fezouata Biota (Lower Ordovician, Morocco). Palaios, 33:535-541. https://doi.org/10.2110/palo.2018.055

Stewart, S.E. and Owen, A.W. 2008. Probing the deep shelf - a Lagerstätte from the Upper Ordovician of Girvan, southwestern Scotland. Lethaia, 41:139-146. https://doi.org/10.1111/ j.1502-3931.2008.00117.x

Topper, T.P., Strotz, L.C., Holmer, L.E., Zhang, Z.F., Tait, N.N., and Caron, J.-B. 2015. Competition and mimicry: the curious case of chaetae in brachiopods from the middle Cambrian Burgess Shale. BMC Evolutionary Biology, 15:42:1-16. https://doi.org/10.1186/ s12862-015-0314-4

Torsvik, T.H. 2009. BugPlates: Linking biogeography and palaeogeography. Available online at http://www.iggl.no/resources.html (accessed September 2017).

Tripp, R.P. 1980. Trilobites from the Ordovician Balclatchie and lower Ardwell groups of the Girvan district, Scotland. Transactions of the Royal Society of Edinburgh: Earth Science, 71:123-45. https://doi.org/10.1017/S0263593300019192

Vandenbroucke, T., Verniers, J., and Clarkson, E.N.K. 2003 (for 2002). A chitinozoan stratigraphy of the Upper Ordovician and lower Silurian strata of the Girvan area, Midland valley, Scotland. Transactions Royal Society Edinburgh, Earth Sciences, 93:111-134. https:// doi.org/10.1017/S0263593300000365

Vinn, O. 2017. Early symbiotic interactions in the Cambrian. Palaios, 32:231-237. https://doi.org/ 10.2110/palo.2016.092

Van Roy, P., Orr, P.J., Botting, J.P., Muir, L.A., Vinther, J., Lefebvre, B., El Hariri, K., and Briggs, D.E.G. 2010. Ordovician faunas of Burgess Shale type. Nature, 465:215-218. https://doi.org/ 10.1038/nature09038

Walcott, C.D. 1920. Cambrian geology and paleontology IV, no. 6 - Middle Cambrian Spongiae. Smithsonian Miscellaneous Collections, 67:261-364.

Williams, A. 1963. The Caradocian brachiopod faunas of the Bala district, Merionethshire. Bulletin of the British Museum (Natural History), Geology, 8:327-471.

Zhang, Y.D., Chen, X., Goldman, D., Zhang, J., Cheng, J.F., and Song, Y.Y. 2010. Diversity and paleobiogeographic distribution patterns of Early and Middle Ordovician graptolites in distinct depositional environments of South China. Science China (Earth Sciences), 40(9):11641180. https://doi.org/10.1007/s11430-010-4088-7 